\title{
Employee stock ownership plan and stock price crash risk
}

\author{
Yan $\mathrm{Li}^{1}$, Bao Sun ${ }^{1}$ and Shangyao $\mathrm{Yu}^{2^{*}}$
}

\author{
* Correspondence: yushangyao@ \\ btbu.edu.cn \\ ${ }^{2}$ Business School, Beijing \\ Technology and Business University, \\ Beijing 100048, China \\ Full list of author information is \\ available at the end of the article
}

\begin{abstract}
This paper examines whether the announcement of an employee stock ownership plan (ESOP) affects stock price crash risk and the mechanism by which the ESOP may influence crash risk, using a sample of Chinese A-share firms from the period 2014 to 2017. We provide evidence that an ESOP announcement is significantly and negatively related to a firm's stock price crash risk. An ESOP announcement sends positive signals to the market that insiders are optimistic about a firm's future value, which helps enhance investor confidence, resist the pressure for a fire sale caused by negative information disclosure, and reduce stock price crash risk. Further research shows that larger-scale, lower-priced and non-leveraged ESOPs are more helpful in reducing crash risk. This paper sheds lights on the impact of ESOPs in a volatile market environment. It also contributes to firms' implementation of ESOPs and the development of the legal system in capital markets.
\end{abstract}

Keywords: Employee stock ownership plan (ESOP), Crash risk, Market situation, Signaling effect, Leveraged ESOP, China

\section{Introduction}

The China Securities Regulatory Commission (CSRC) issued the "Guiding Opinions on the Pilot Program for the Implementation of the Employee Share Ownership Plans by Listed Companies" ("Opinions") on June 20, 2014. ESOPs have been attracting more and more attention and recognition from China's listed companies. By December 31, 2017, more than 816 Chinese A-share listed companies had successively implemented ESOPs and many other companies have indicated that they intend to implement ESOPs. Are ESOPs an effective means to stabilize market sentiment and stock prices or an accelerator for market fluctuations and crash? The answer to this question is important to listed firms and regulators, especially in China where ESOPs are still relatively new and stock markets are still underdeveloped and often suffer from systematic sharp downturns.

There is considerable research on ESOPs and stock price crash risk respectively in the existing literature. However, limited research has been conducted on the influence of ESOPs on stock price crash risk directly. The most related research may be the influence of executive equity incentives on stock price crash risk. Ismail et al. (2016) argue that executives are more likely to announce good news in a timely manner and conceal bad news after the adoption of executive equity incentives. Kim et al. (2011b) study the relationship between executive equity incentives and stock price crash risk.

(c) The Author(s). 2019 Open Access This article is distributed under the terms of the Creative Commons Attribution 4.0 International License (http://creativecommons.org/licenses/by/4.0/), which permits unrestricted use, distribution, and reproduction in any medium, provided you give appropriate credit to the original author(s) and the source, provide a link to the Creative Commons license, and indicate if changes were made. 
They find that CFO option incentives increase future stock price crash risk. These two studies indicate that the relationship between ESOPs and crash risk may be positive.

However, although there are some similarities between ESOPs and executive equity incentives, the influence of ESOPs on stock price crash risk may be very different from that of executive equity incentives. First, as executive equity incentives target the top executives or executive team, the range of targets is often limited. The scope of ESOPs is undoubtedly wider and includes a substantial number of or most employees aside from executives. The number of insiders committed to firm value greatly increases and the difficulty executives have in concealing a firm's bad news is significantly higher after the adoption of an ESOP. Second, executives can exercise their options at any time after the exercise date in executive equity incentives in the form of stock options; hence they only need to pay attention to the stock price when they exercise their options. However, the selling of stock in the case of an ESOP needs the unanimous consent of the shareholder committee and must comply with strict laws and regulations. It is more complicated, difficult and time-consuming. Therefore, an ESOP is likely to contribute more to the long-term value of a firm instead of increasing the short-term stock price by concealing bad news. Last but not least, stock ownership incentives are often offered to executives freely or at a very low price, meaning money on the table for executives. Executives benefit as stock price increases and suffer no losses when prices drop. However, participation in ESOPs is not free. Employees need to pay for ESOPs in accordance with (in the case of purchase from the secondary market) or in reference to (in the case of private placement) the market price, even needing to assume extra liabilities in the case of leveraged ESOPs. If share prices fall below the ESOP purchase price, participants will suffer extra losses, and even go bankrupt due to margin closeout in the case of leveraged ESOPs. Therefore, compared with executive equity incentives, ESOP participants may be more conservative and less likely to increase share prices through short-term risk-taking behaviors increasing future crash risk. For these reasons, we assume that ESOPs may reduce stock price crash risk rather than increase it like executive equity incentives do.

To examine the actual influence of ESOPs on stock price crash risk, we conduct empirical tests using Chinese listed firms who adopted ESOPs from 2014 to 2017. Empirical results show that the announcement of an ESOP significantly decreases a firm's future stock price crash risk. The mechanism by which ESOPs affect crash risk is mainly through signaling effects, namely, ESOPs convey positive signals to the market that insiders are optimistic about the firm's future value, which helps build investors' confidence in the firm, mitigates the fall in stock price or a fire sale on stocks if there is bad news, and thus reduces stock price crash risk. The positive signals ESOPs convey to capital markets also include the likelihood that employees participating in ESOPs are more motivated in exposing firms' bad news, especially when their shares are within a lock-in period. This finding is consistent with previous research, which focuses mainly on the announcement effect of ESOPs. Beatty (1995) shows that ESOP announcements may provide investors with signals about firms' tax avoidance and anti-takeover behaviors. Conte et al. (1996) investigate the financial return and market reaction of ESOP announcements. They find that an ESOP announcement is a good signal to buy a firm's stock. Banerjee et al. (2017) examine the stock price performance of ESOP firms during economic crisis and recovery and find that ESOPs predict a lower fall in market 
capitalization during a crisis and a greater rise in market capitalization at the end of the crisis. External shareholders pay close attention to information signals generated by managerial actions [ESOPs and Seasoned Equity Offerings (SEOs)] that indicate resilience during an economic crisis.

This paper also finds that the impact of ESOPs on stock price crash risk depends on the characteristics of the ESOPs. In particular, the link between ESOPs and stock price crash risk is more pronounced in larger-scale ESOPs, which is consistent with the findings on the signaling effect of ESOPs, as larger-scale ESOPs convey stronger signals about employees' optimistic views on firms' future value. ESOPs with high prices or financial leverage do not reduce crash risk and sometimes even raise it, which is inconsistent with the signaling effect. However, these inconsistent results do not mean the signaling effect is ineffective, but indicate special signals about liquidation pressure in a harsh market environment, which offset the positive signals sent by the ESOPs. Our results are robust to various sensitivity analyses.

Our study makes several contributions. First, this study contributes to the literature on the impact of ESOPs. This paper is the first so far directly testing the influence of ESOPs on the stability of capital markets from the perspective of stock price crash risk, while previous research focused mainly on employees' attitudes, firm performance, market reactions and abnormal returns. Our study enriches the perspectives on ESOP influence and is a necessary supplement to the existing literature.

Second, our study extends literature on the influence factors of stock price crash risk. Existing literature on factors affecting stock price crash risk mainly takes into account the concealment and concentrated disclosures of bad news, while this paper includes ESOPs into the study framework of stock price crash risk, and examines the influencing factors of stock price crash risk from the perspectives of insiders' signals sending and investor behaviors, which is an important extension of the existing literature.

Finally, this paper uses a specific period, namely "the stock market crash in 2015" to examine the impact of ESOPs on crash risk. It is a beneficial supplement to specific and situated studies on ESOPs, and it also sheds light on the further establishment and improvement of the relevant laws and regulations to the regulatory authorities.

The remainder of this paper is organized as follows. Institutional background introduces the history and basic background of ESOPs in China. literature review and hypotheses development section presents the literature review and theoretical hypotheses. Research design section describes the study design. In empirical results section, analysis and explanation of empirical results are presented. Conclusion section concludes.

\section{Institutional background}

ESOPs in China have emerged with the development following the reform and opening up policy of China and the reform of state-owned enterprises (SOEs). The first ESOP took place in a state-owned department store in 1984 with the approval of the Chinese government. This store is also the first company in China to complete shareholding reform. Since then, the number of ESOPs has increased rapidly. By the end of 1987, more than 3,200 enterprises in China had carried out shareholding reforms, of which more than $80 \%$ adopted ESOPs.

In 1992, the Chinese government started the process of corporatization in SOEs. SOEs were allowed to adopt ESOPs with the approval of the regulatory authorities, 
which led to a further increase in the number of companies that implemented ESOPs. However, ESOPs at that time were far from formal, and a series of key issues were not clear. Abuse of public power and corruption emerged as the number of ESOPs expanded. As such, the government gradually stopped approving new applications for ESOPs and the implementation of ESOPs was actually stagnating.

To sum up, it is impossible to research the influence of ESOPs on capital markets at this stage, as only two major stock exchanges in China, the Shanghai Stock Exchange and the Shenzhen Stock Exchange, had just officially come into existence and only eight stocks were traded in 1990. Most firms adopting ESOPs at that time were nonlisted companies. The adoption of an ESOP cannot be regarded as an independent market-driven choice of a firm, for adoption and termination were both under the control of the government.

Almost 20 years later, the CSRC issued the "Opinions" on June 20, 2014, which indicated the resurgence of ESOPs in China. By the end of 2017, 816 out of 3,468 Chinese A-share listed companies had successfully implemented ESOPs and many other companies have the intention of adopting ESOPs. In addition, a large number of non-listed companies, especially start-ups and high-tech ones have also implemented ESOPs.

Unlike in the US, where ESOPs are typically used as a pension plan (e.g., Holden and Van Derhei 2003; Mitchell and Utkus 2002; Rauh 2006) and a means to conserve cash in lieu of wages (e.g., Core and Guay 2001; Kim and Ouimet 2014; Poterba 2004), ESOPs in Chinese firms, especially in listed firms, are adopted in the hope of establishing a benefit-sharing system between workers and owners, improving corporate governance, enhancing employee cohesion and the competitiveness of a company. All of this is covered in the "Opinions."

In reality, ESOPs are often used by start-ups and high-tech companies as a means of retaining core employees (so-called "golden handcuffs"), which means that ESOPs in China emphasize incentives and benefits-sharing. Because of a lack of cash, there is indeed a phenomenon of substituting equity for wages in some Chinese start-ups. However, this is not the case in China's listed firms though employees pay for shares with their future wage earnings in most ESOPs, which may reduce cash outflows of wage payment. The implementation of an ESOP does not improve the cash holdings of a company, for less than a third of ESOPs in our sample are implemented through the offering of new shares. Cash from ESOPs flow more to the stock market than to ESOP firms through block transactions and secondary market acquisitions. In fact, due to the existence of leveraged ESOPs, the implementation of ESOPs has somewhat deteriorated firms' financing ability rather than improving firms' cash holdings. As a provider of leveraged capital, financial institutions usually require a guarantee from ESOP firms or their major shareholders. Due to the severe shocks in the China's stock market in 2015, firms that had implemented leveraged ESOPs and their major shareholders assumed huge joint and several guarantee liability. In order to avoid compulsory liquidation, some even repaid the leveraged capital in advance with their own funds.

ESOPs are also regarded as an effective anti-takeover tool (e.g., Beatty 1994; Chang and Mayers 1992; Chaplinsky and Niehaus 1994; Gordon and Pound 1990; Park 2017; Rauh 2006) in the US with fully decentralized stock ownership. However, the ownership structure of listed firms in China is relatively centralized. According to the 2017 annual report of A-share listed companies in China, among all 3,512 listed companies, 
the average shareholding ratio of the largest shareholder is $33.8 \%$ and 520 companies account for more than $50 \%$ of the largest shareholders. Considering that there may be common ultimate controllers among different shareholders, the actual ownership concentration is higher than these figures. Correspondingly, the shareholding ratio of ESOPs in China is only $1.68 \%$, which only has a minimal impact on firms' ownership structure and would not be able to prevent a takeover.

According to the "Opinions," the total shareholding ratio of ESOPs shall not exceed $10 \%$, and the single employee stock ownership ratio shall not exceed $1 \%$. Considering that ESOP participants are usually hundreds or even thousands of employees and the shareholding ratio of ESOPs in China is less than 2\%, the shareholding ratio of a single employee is even smaller. The free riding behavior of ESOP participants maybe a problem to be considered (Brown et al. 1999; Comment and Jarrell 1987; Kim and Ouimet 2014). However, we argue that free riding behavior is not a causative problem in this paper; instead, ESOP participants may be the active shareholders that shareholder activism theory has been looking for, especially in the Chinese context. Free riding problems in ESOPs occur mainly in reducing productivity or firm performance (e.g., Kim and Ouimet 2014). Employees may behave differently in supervising management and disclosing negative information. Dyck et al. (2010) find that $17 \%$ of U.S. firms' financial fraud is first disclosed by employees. The number of active employees needed to improve productivity and supervise management may be totally different. In other words, only one active employee in the firm may have no effect on improving productivity, but one is enough for information disclosure. There are many factors that can change an ordinary employee into an active one. These factors are sometimes even not worth mentioning from the perspective of corporate governance and incentives. For example, a Chinese listed firm, Changsheng Biotechnology Co., Ltd. (stock code: 002680), was fined RMB9.1 billion and forced to withdraw from the stock market for promulgating fake vaccines in 2018. This event, which forced the CSRC to amend the rules for compulsory delisting of listed firms, was first exposed by employees within the firm, whose initial motivation was that the company did not pay their overtime wages on time. Participation in an ESOP presumes a closer link between the employees' and the firm's interests than overtime wages. Once employees have been injured, they are more likely to become active employees and expose bad news about the firm, which in turn affects the firm's stock price and the stock price crash risk.

Finally, in China, ESOPs are still relatively new, and investors may not fully understand what an ESOP is. Since the Chinese stock markets and investors are far from mature, there may be deviations in the market reactions to ESOPs.

\section{Literature review and hypotheses development}

The existing literature on ESOPs and on stock price crash risk is extensive; however, few studies have been conducted on the relationship between ESOPs and stock price crash risk directly. As a mechanism linking employees' interests and firms' future value, ESOPs are often regarded as an effective incentive measure, which can encourage employees' motivation (Akerlof 1982; Buchko 1992; Hammer et al. 1981), improving firm performance (Ahrens 2018; Conte and Tannenbaum 1978; Kumbhakar and Dunbar 1993; Pugh et al. 2000; Quarrey et al. 1986; Rosen and Quarrey 1987). The capital market generally considers ESOP announcements to be positive signals of stock price 
which result in positive market reactions (Ding and Sun 2001; De Fusco et al. 1990; Fang et al. 2015; Tehranian and Waegelein 1985; Triki and Ureche-Rangau 2012). Overall, ESOPs are considered to be helpful in enhancing firm value and stock price.

The existing literature shows that stock price crash risk is due to the concealment and subsequent concentrated outbreak of bad news. In consideration of private benefits, such as political promotion (Piotroski et al. 2015), tax avoidance (Kim et al. 2011a) and stock ownership incentives (Kim et al. 2011b), executives are motivated to disclose firms' good news in a timely manner while concealing bad news as far as possible. However, hoarded bad news is suddenly revealed once concealment fails, which has a negative impact on stock price and eventually leads to stock price crash (Xu et al. 2013). Therefore, the key to reducing stock price crash risk lies in timely and effective information disclosure and avoidance of bad news hoarding (Jin and Myers 2006).

Building on the existing research, we propose two different effects of ESOPs on stock price.

On the one hand, ESOPs may be negatively related to crash risk. ESOPs send positive signals to the market that insiders are optimistic about a firm's value (Tehranian and Waegelein 1985), and these signals are often reliable for the following reasons. First, not all firms can successfully issue an ESOP. An ESOP may be terminated if the board of directors votes to oppose it, if it is vetoed by shareholders, or if employees choose not to participate. In fact, more than 200 ESOPs have not been successfully issued for these reasons from 2014 to 2017 in China. The successful issuance of an ESOP represents the unanimous judgment of directors, shareholders and employees on the value of the firm. Second, participating in an ESOP is a voluntary and independent decision made by employees rather than a compulsory act under firms' administrative orders; therefore it is a better way to show the employees' evaluation of firm value than other channels such as corporate marketing and media reports. Third, employees need to pay for ESOPs, sometimes assuming extra liabilities, which make ESOP participation a high cost and risky decision. Employees will not participate in the ESOP unless they do believe in the firm's future value. It is highly unlikely that employees would participate in an ESOP just to raise stock price and mislead investors.

Therefore, an ESOP announcement can upgrade investors' estimates of the firm's future value, help build investors' confidence in the firm, reduce the possibility of a stock fire sale due to short-term negative news, and decrease a firm's future stock price crash risk. The higher the cost employees pay for participating in an ESOP, the stronger the signal sent to capital markets. Larger-scale, higher-priced and leveraged ESOPs are more signaling than otherwise. The signaling effect of an ESOP on crash risk can also work through motivating employees to disclose firms' bad news. Internal employees are one of the most important ways a firm's bad news is exposed (Dyck et al. 2010). An ESOP strengthens the link between employees' wealth and firm stock price performance. Employees are more motivated to disclose bad news in order to prevent possible declines in stock price caused by a concentrated outbreak of bad news when they sell their stocks. This will also enhance investors' confidence in a firm's future value and reduce crash risk. Based on the signaling hypothesis, we predict that ESOPs send positive signals to the market about a firm's value, reduce negative reactions to bad news and ultimately decrease stock price crash risk. 
On the other hand, ESOPs may increase crash risk under specific circumstances. As a tool linking shareholders' benefits with employees' (Hall and Murphy 2000, 2002, 2003; Huddart 1994; Jensen and Murphy 1990; Kim and Ouimet 2011), employees share not only the benefits but also the risks with the firm after the adoption of an ESOP. Participants in an ESOP will suffer extra losses if share prices drop dramatically after the adoption of an ESOP. As employees are generally considered to be risk neutral or even risk averse (Agrawal and Mandelker 1987; Cohen et al. 2000; De Fusco et al. 1990; Haugen and Senbet 1981; Rajgopal and Shevlin 2002), an ESOP committee may sell off shares to stop losses when share prices fall sharply. ESOPs may be forced to sell off shares in the form of a margin close out in the case of leveraged ESOPs, if the margin is not replenished or no other remedial measures are taken. These active or passive trading practices will accelerate the drop of stock price and increase crash risk. Second, considering that the ESOP is now a hot topic in China's capital markets, announcements of ESOPs are more likely to attract analysts' optimistic bias and forecasting may also increase a firm's stock price crash risk (Xu et al. 2013).

Therefore, we propose two competing hypotheses.

Hypothesis 1a: ESOP announcements are negatively related to firms' future stock price crash risk.

Hypothesis 1b: ESOP announcements are positively related to firms' future stock price crash risk.

\section{Research design}

\section{Sample selection}

Our sample period is from the second half of 2014 to the end of 2017. The CRSC issued the "Opinions" on June 20, 2014, which indicates that ESOPs had officially become a stock ownership incentive for Chinese listed companies by that time. It is noteworthy that 2014 is not the first year ESOPs came to China. For example, Chinese SOEs have been allowed to be privatized into incorporated companies and adopt ESOPs with the approval of regulatory authorities since 1992. However, ESOPs at that time were to some extent mandatory, unplanned and nonstandard. Most firms adopting ESOPs were non-listed and therefore did not need to pay attention to crash risk.

All of our research data comes from CSMAR and WIND databases, two of the most publicly used and widely accepted databases in financial and economic research in China. The financial and stock exchange data of listed firms used to calculate stock price crash risk are sourced from the CSMAR database. Employee stock ownership data of listed companies are sourced from the WIND database. ESOP partial characteristic data, such as ESOP size, price, and leverage ratio, are collected manually from provisional announcements of listed firms.

We collect data from 816 cases of ESOPs in China announced from the second half of 2014 to the end of 2017, and remove cases with missing or abnormal values which could not be refilled manually, which reduces our ESOP cases to 783. Meanwhile, in order to address the endogeneity problem caused by differences in firm characteristics, and examine the influence of ESOP announcements on stock price crash risk accurately, we conduct propensity score matching (PSM) for ESOP firms. ESOP paired firms 
are in the same industry and most similar in terms of total assets (Ding and Sun 2001; Jones and Pliskin 1997), return on assets (Beatty 1994), shareholding ratio of the largest shareholder (Beatty 1994) and debt liability, which previous research has demonstrated impacts the decision to adopt an ESOP. The ratio of event firms to the paired ones is 1:1. Finally, we obtain a full sample of 4,832 observations from 1,566 event and paired firms.

Existing literature on stock price crash risk generally uses quarterly data; this paper, however, employs half-year data, as the quarterly data of some control variables (e.g., the information transparency of listed firms measured as the accrual earnings) in the empirical models are unavailable due to the information disclosure rules of the Chinese stock markets.

Table 1 reports the number of ESOP adoptions. The number of ESOP adoptions had increased gradually from the second half of 2014 to the end of 2015. The adoption of ESOPs fell sharply in 2016, mainly because China's stock market experienced a big crash in 2015 and the confidence of the firm's major shareholders and employees in the stock market had not yet been restored.

\section{Measuring crash risk}

We employ two measures of stock price crash risk, following Chen et al. (2001), Hutton et al. (2009) and Kim et al. (2011a, 2011b). Both measures are based on firm-specific weekly returns estimated as the residuals from the market model. To calculate firmspecific weekly returns, we estimate the following expanded market model regression.

$$
R_{i, t}=\alpha_{0}+\alpha_{1} R_{m, t-2}+\alpha_{2} R_{m, t-1}+\alpha_{3} R_{m, t}+\alpha_{4} R_{m, t+1}+\alpha_{5} R_{m, t+2}+\varepsilon_{i, t},
$$

where $R_{i, t}$ is the return of stock $i$ in week $t, R_{m, t} \mathrm{r}_{\mathrm{m}, \mathrm{t}}$ is the value-weighted return of all China A-share stocks in week $t$. The firm-specific return $W_{i, t}$ is measured by the natural $\log$ of one plus the residual return in Eq. (2):

$$
W_{i, t}=\ln \left(1+\varepsilon_{i, t}\right),
$$

where $\varepsilon_{i, t}$ is the regression residual of Eq. (1).

Based on $W_{i, t}$, our first measure of crash risk is the negative conditional skewness of firm-specific weekly returns over the past 6 months (NCSKEW), Specifically, for each firm $i$ in period $t, N C S K E W$ is calculated as:

$$
N \operatorname{NSKE} W_{i, t}=-\left[n(n-1)^{3 / 2} \sum_{i=1}^{n} W_{i, t}^{3}\right] /\left[(n-1)(n-2)\left(\sum_{i=1}^{n} W_{i, t}^{2}\right)^{3 / 2}\right],
$$

where $W_{i, t}$ is the firm-specific weekly return defined above and $n$ is the number of weekly returns during period $t$. A negative sign is put such that a higher value of NCSKEW indicates higher crash risk.

Our second measure of crash risk is the down-to-up volatility (DUVOL). For each firm $i$ over the period $t$, firm-specific weekly returns are separated into two groups, "down" weeks when the returns are below the mean of firm-specific weekly returns over the last 6 months, and "up" weeks when the returns are above it. Then we calculate the standard deviation of firm-specific weekly returns for each of these two groups 
Table 1 Semiannual ESOP adoptions and observations

\begin{tabular}{lll}
\hline Semiannual & ESOP adoptions & ESOP firm-semiannual observations \\
\hline $2014-2$ & 49 & 98 \\
$2015-1$ & 146 & 390 \\
$2015-2$ & 208 & 666 \\
$2016-1$ & 103 & 808 \\
$2016-2$ & 70 & 896 \\
$2017-1$ & 103 & 1032 \\
$2017-2$ & 104 & 942 \\
Total & 783 & 4832 \\
\hline
\end{tabular}

Notes. This table reports the number of ESOP adoptions and the number of firm-semiannual observations identified through PSM from the second half of 2014 (2014-2) to the second half of 2017 (2017-2)

separately. DUVOL is the natural logarithm of the ratio of the standard deviation in the "down" weeks to the standard deviation in the "up" weeks:

$$
D_{U V O L}, t=\ln \left\{\left[\left(n_{u}-1\right) \sum_{\text {down }} R_{d}^{2}\right] /\left[\left(n_{d}-1\right) \sum_{u p} R_{u}^{2}\right]\right\},
$$

where $n_{u}$ is the number of up weeks and $n_{d}$ is the number of down weeks over the past 6 months.

\section{Empirical model}

\section{ESOPs and stock price crash risk}

To investigate the effect of ESOPs on crash risk, we first estimate the following regression:

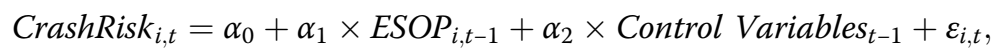

where CrashRisk ${ }_{i, t}$ represents stock price crash risk of firm $i$ during the time period $t$, which is measured by the negative conditional skewness of firm-specific weekly returns over the past 6 months (NCSKEW) and the down-to-up volatility measure (DUVOL) of the crash likelihood; $E S O P_{i, t-1}$ is a dummy variable representing whether firm $i$ adopts an ESOP during the time period $t-1$, valued at 1 if the firm has announced the adoption of ESOP, and 0 otherwise.

We also use the follow indexes to measure firm ESOP in the subsequent empirical tests:

(1) The scale of ESOP stocks (Size_ESOP, Stock_ESOP)

Size_ESOP is the fund scale of an ESOP, which is measured by the natural logarithm of all capital invested in an ESOP (including employees' own money and funds from leveraged financing). Once an ESOP is announced, external investors may judge a firm's future value based on the size of the ESOP. For example, a small-scale ESOP may means that employees are not so optimistic about the firm's future and are not willing to invest a lot of money in the firm's ESOP, which will certainly affect the ESOP's market reaction. We employ this variable to differentiate the market reaction to different capital scales in ESOPs. 
Stock_ESOP is the shareholding ratio of an ESOP, which is measured as the ratio of ESOP shares to the firm's total outstanding ones. Considering that the variable Size ESOP is closely related to the size of the firm, in order to eliminate this correlation, we introduce Stock_ESOP to further test the market reaction of ESOPs of different sizes.

(2) The price of ESOPs (Price_ESOP, $R \_$Price_ESOP)

Price_ESOP is the estimated share price of an ESOP disclosed in the Draft of Employee Stock Ownership Plan. The estimated share price of an ESOP is not only directly related to the future returns of the ESOP, but also reflects the insider judgment on future share price, which will undoubtedly affect the final market reaction. We employ this variable to differentiate the market reaction to the level of share price at which the ESOP is issued.

R_Price_ESOP is the ratio of estimated share price to the closing price of the shares on the date the ESOP was announced. ESOP share price is based on the firm's share price at the time the ESOP was announced, and there is significant difference in prices between different stocks, which may reduce the information content of variable Price ESOP. In order to control for this problem, we employ variable $R \_$Price_ESOP to further test the market reaction of ESOPs of different price levels.

(3) The leverage of ESOPs (Dum_lev_ESOP, Lev_ESOP)

Dum_lev_ESOP is a dummy variable representing whether an ESOP is leveraged, valued at 1 if funds used in the ESOP involve debt financing from other financial institutions, and 0 otherwise. A leveraged ESOP implies a higher risk for employees, the firm or its major shareholders with joint and several liability for security than a general ESOP. The willingness to adopt a leveraged ESOP may mean that employees are more optimistic about the firm's future value, which will also affect the external investors' judgment of the firm's value, and thus the market reaction. Therefore, we employ this variable to differentiate the market reaction to the level of ESOP leverage.

Lev_ESOP is the ratio of debt financing to employees' own money in the ESOP. This variable is employed to further test the difference of market reaction to the level of ESOP leverage.

ControlVariables $_{i, t-1}$ are the control variables. Following Chen et al. (2001), Hutton et al. (2009), and Kim et al. (2011a, 2011b), we use the following variables as control variables:

(1) Change of trading volume (Dturn), calculated as the average monthly share turnover in period $t$ minus the average monthly share turnover in $t-1$;

(2) Stock return over the past 6 months (Hret), calculated as the mean of firm-specific weekly returns over the fiscal year;

(3) Stock volatility (Sigma), calculated as the standard deviation of firm-specific weekly returns over the past 6 months;

(4) Firm size (Size), calculated as the log value of the market value of equity;

(5) The market-to-book ratio $(M B)$, calculated as the market value of a firm divided by its book value of equity; 
(6) The firm's asset liability ratio (Lev), calculated as total long-term debts divided by total assets;

(7) Profitability $(R O A)$, calculated as net profits divided by total assets;

(8) Earnings management $(D A)$, the absolute value of abnormal accruals estimated by the modified Jones model.

As well, we control the lag value of crash risk to account for the potential serial correlation for the sample firms. All of our regressions include industry and time fixed effects.

To eliminate the influence of extreme values on our findings, we winsorize continuous variables by replacing all outliers with the 5th and 95th percentiles.

Table 2 presents the descriptive statistics for the variables used in our regression analysis. Panel A of Table 2, which contains both firms adopting ESOPs and their paired ones, reports the descriptive statistics for the full sample, and gives an overview of the China stock markets in terms of trading volume (Dturn), half year return (Hret), stock price volatility (Sigma), firm size (Size), market to book ratio $(M B)$, leverage ratio (Lev), return on assets $(R O A)$, earnings management $(D A)$, and stock price crash risk (NCSKEW and DUVOL).

More details of ESOPs in China are presented in panel B of Table 2. The size of ESOPs after logarithmic (Size_ESOP) is 9.310, about 1.679\% of firms' total stock (Stock_ESOP). The expected ESOP price (Price_ESOP) is 19.51, which is equivalent to a $30.8 \%$ discount of the closing price on the ESOP announcement date $\left(R_{-}\right.$ Price_ESOP). $44.9 \%$ of ESOPs are leveraged (Price_ESOP); the average proportion of leveraged funds to employees' own money is $71.6 \%$ (Lev_ESOP).

Signaling effect of ESOPs on crash risk

To test whether the signaling mechanism of ESOPs on crash risk works, we run the following empirical model:

$$
\begin{aligned}
\text { CrashRisk }_{i, t}=\alpha_{0} & +\alpha_{1} \times \text { ESOP }_{i, t-1} \times \text { Signal }_{i, t-1}+\alpha_{2} \times \text { ESOP }_{i, t-1} \\
& +\alpha_{3} \times \text { Signal }_{i, t-1}+\alpha_{4} \times{\text { Control } \text { Variables }_{t-1}+\varepsilon_{i, t},},
\end{aligned}
$$

where Signal ${ }_{i, t-1}$ is a dummy variable representing a firm's negative information. We use three methods to describe a firm's negative information: A dummy variable of whether the firm's earnings per share (EPS) is lower than analysts' consensus expectation (DEPS), a dummy variable of whether the firm has been penalized by the CSRC (Punish) in the past 6 months, and a dummy variable of whether the firm is involved in lawsuits as a defendant (Lawsuit).

Notice that these three variables DEPS, Punish and Lawsuit represent the quality of the firm to a certain extent, which may affect the original crash risk level and cause some endogeneity problems. However, crash risk is caused by a concentrated outbreak of bad news, rather than "bad" firms. We employ these three variables to test the influence of ESOPs on crash risk when bad news does exist and breaks out. If ESOPs do send positive signals to external investors about firms' future value and produce confidence in stock price, the influence of negative information should be weakened and the stock price should drop less or not at all. 
Table 2 Descriptive statistics

\begin{tabular}{|c|c|c|c|c|c|c|}
\hline Variable & No. of obs. & Mean & P1 & Median & P99 & Std \\
\hline \multicolumn{7}{|c|}{ Panel A: Event group (firms adopting ESOPs) + paired group } \\
\hline NCSKEW & 4832 & -0.341 & -1.745 & -0.435 & 1.337 & 0.764 \\
\hline DUVOL & 4832 & -0.256 & -1.375 & -0.312 & 0.946 & 0.575 \\
\hline ESOP & 4832 & 0.500 & 0 & 1 & 1 & 0.500 \\
\hline Dturn & 4832 & -0.315 & -9.295 & -0.266 & 4.188 & 1.552 \\
\hline Hret & 4832 & -0.013 & -0.336 & -0.081 & 1.407 & 0.036 \\
\hline Sigma & 4832 & 0.030 & 0.013 & 0.026 & 0.064 & 0.013 \\
\hline Size & 4832 & 22.239 & 20.598 & 22.146 & 24.015 & 0.931 \\
\hline$M B$ & 4832 & 2.871 & 0.027 & 2.147 & 12.597 & 3.042 \\
\hline Lev & 4832 & 0.412 & 0.146 & 0.402 & 0.720 & 0.181 \\
\hline$R O A$ & 4832 & 2.140 & -0.788 & 1.870 & 5.728 & 1.807 \\
\hline$D A$ & 4832 & -0.017 & -0.203 & -0.026 & 0.182 & 0.109 \\
\hline \multicolumn{7}{|c|}{ Panel B: Sub-sample of companies adopting ESOPs } \\
\hline NCSKEW & 2416 & -0.353 & -1.745 & -0.446 & 1.337 & 0.760 \\
\hline DUVOL & 2416 & -0.276 & -1.254 & -0.328 & 0.946 & 0.568 \\
\hline Stock_ESOP & 2416 & 1.679 & 0.030 & 1.260 & 7.270 & 1.501 \\
\hline Size_ESOP & 2416 & 9.310 & 6.358 & 9.220 & 11.918 & 1.145 \\
\hline Price_ESOP & 2416 & 19.510 & 3.140 & 15.790 & 84.140 & 14.765 \\
\hline R_price_ESOP & 2416 & 0.692 & 0 & 0.853 & 1.769 & 0.489 \\
\hline Dum_Lev_ESOP & 2416 & 0.449 & 0 & 0 & 1 & 0.498 \\
\hline Lev_ESOP & 2416 & 0.716 & 0 & 0 & 6.301 & 1.719 \\
\hline Dturn & 2416 & -0.296 & -4.341 & -0.250 & 3.910 & 1.466 \\
\hline Hret & 2416 & -0.006 & -0.336 & -0.078 & 1.540 & 0.318 \\
\hline Sigma & 2416 & 0.030 & 0.013 & 0.026 & 0.064 & 0.014 \\
\hline Size & 2416 & 22.235 & 20.737 & 22.157 & 24.015 & 0.881 \\
\hline$M B$ & 2416 & 2.819 & 0.201 & 2.235 & 11.080 & 2.389 \\
\hline Lev & 2416 & 0.411 & 0.146 & 0.404 & 0.720 & 0.176 \\
\hline$R O A$ & 2416 & 2.180 & -0.788 & 1.985 & 5.728 & 1.741 \\
\hline$D A$ & 2416 & -0.023 & -0.203 & -0.031 & 0.182 & 0.106 \\
\hline
\end{tabular}

Notes. This table presents descriptive statistics on stock price crash risk, executive compensation, and control variables. The sample contains firms adopting ESOPs from 2014 to 2017 and their paired firms. All variables are defined in section 3.2

\section{Empirical results}

\section{ESOPs and stock price crash risk}

To examine the relationship between ESOPs and stock price crash risk, we estimate Eq. (5) using matched samples obtained through propensity score matching (PSM). Full samples without PSM are also included in Table 3 to ensure the effectiveness of our PSM approach and to control for the selective bias caused by PSM.

Table 3 presents the regression results. Columns (3) and (4) report the results of regressions using matched samples, where crash risk is measured by the negative conditional skewness of firm-specific weekly returns over the past 6 months (NCSKEW) and the down-to-up volatility $(D U V O L)$ respectively. Results show that ESOP 
Table 3 Impact of ESOPs on stock price crash risk

\begin{tabular}{|c|c|c|c|c|}
\hline \multirow[t]{2}{*}{ Variable } & \multicolumn{2}{|l|}{ Full samples } & \multicolumn{2}{|l|}{ Paired samples } \\
\hline & NCSKEW (1) & DUVOL (2) & NCSKEW (3) & DUVOL (4) \\
\hline$E S O P_{i, t-1}$ & $-0.104^{c}(-3.16)$ & $-0.109^{c}(-4.19)$ & $-0.025^{b}(-2.22)$ & $-0.038^{b}(-2.47)$ \\
\hline Dturn $_{i, t-1}$ & $0.003(0.63)$ & $0.004(0.91)$ & $0.007(0.99)$ & $0.007(1.25)$ \\
\hline Hret $_{i, t-1}$ & $0.238^{\mathrm{c}}(22.09)$ & $0.151^{c}(16.87)$ & $0.705^{c}(11.83)$ & $0.515^{c}(10.9)$ \\
\hline Sigma $_{i, t-1}$ & $-6.928^{c}(-21)$ & $-5.675^{c}(-21.66)$ & $-2.785(-1.33)$ & $-1.021(-0.65)$ \\
\hline$M B_{i, t-1}$ & $0.02^{\complement}(5.96)$ & $0.015^{\complement}(5.77)$ & $0.016^{c}(3.76)$ & $0.009^{c}(2.88)$ \\
\hline Size $_{i, t-1}$ & $-0.042^{c}(-9.29)$ & $-0.029^{c}(-8.15)$ & $-0.011(-0.70)$ & $-0.022^{\mathrm{a}}(-1.85)$ \\
\hline $\operatorname{Lev}_{i, t-1}$ & $0.028^{b}(2.39)$ & $0.018^{\mathrm{b}}(2.01)$ & $0.128(1.64)$ & $0.041(0.71)$ \\
\hline$R O A_{i, t-1}$ & $0.000(-0.08)$ & $0.000(-0.10)$ & $-0.03^{\mathrm{C}}(-4.69)$ & $-0.031^{c}(-6.60)$ \\
\hline$D A_{i, t-1}$ & $0.000(-0.02)$ & $0.000(-0.11)$ & $-0.138(-1.30)$ & $-0.107(-1.35)$ \\
\hline$N_{C S K E W}$ & $0.067^{c}(10.12)$ & & $0.108^{\complement}(6.87)$ & \\
\hline DUVOL $L_{i, t-1}$ & & $0.077^{C}(10.82)$ & & $0.119^{c}(7.01)$ \\
\hline Intercept & $0.938^{\mathrm{C}}(8.72)$ & $0.68^{\complement}(7.98)$ & $0.075(0.18)$ & $0.524^{a}(1.69)$ \\
\hline Fix_ind & Yes & Yes & Yes & Yes \\
\hline Fix_time & Yes & Yes & Yes & Yes \\
\hline Adj- $R^{2}$ & 0.0541 & 0.0665 & 0.1554 & 0.1799 \\
\hline No. of obs. & 25,391 & 25,391 & 4,832 & 4,832 \\
\hline
\end{tabular}

Notes. This table presents the results of the impact of ESOPs on stock price crash risk using both full samples and paired samples. Full samples cover firms in China A-share markets from 2014 to 2017 with non-missing values for crash risk, ESOPs and control variables. Paired samples cover firms adopting ESOPs and their matched firms through PSM. The empirical test model is

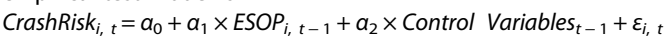

The $t$-statistics, reported in parentheses, are based on standard errors clustered by both firm and time. Time and industry fixed effects are included. Here ${ }^{a},{ }^{b}$, and ${ }^{c}$ indicate statistical significance at the $10 \%, 5 \%$, and $1 \%$ levels, respectively

announcements are negatively related to future crash risk at the $5 \%$ level, indicating that ESOPs can significantly decrease firms' future stock price crash risk.

Columns (1) and (2) report full sample results, which cover all listed firms in the China A-share market from 2014 to 2017. The negative relationship between ESOPs and future crash risk still persists after enlarging our research sample to all listed firms in China. As the PSM approach does not affect the relation between ESOPs and crash risk, samples used in subsequent tests are all matched ones.

In sum, results in Table 3 show that ESOP announcements are negatively related to firms' future crash risk, which indicates that ESOPs can decrease crash risk significantly. This finding supports Hypothesis 1a.

Results in Table 3 may also indicate potential endogeneity problems. As ESOPs are negatively related to stock price crash risk, a firm's stock price and its crash risk may also be determinants of ESOP implementation. Firms with lower crash risk are more likely to adopt ESOPs rather than ESOPs' decreasing firms' crash risk. To control for this problem, we modify the PSM approach in this paper, adding firms' previous crash risk level in matching conditions and re-examine Eq. (5). The results still persist, which indicates that the potential effect of firms' previous crash risk level on ESOP adoption cannot explain the negative relationship between them. However, we do not present this result due to the length of this paper. 


\section{Signaling effect of ESOPs on crash risk}

To examine the signaling effect of ESOPs on crash risk, we run Eq. (6) and estimate the interaction between ESOPs and firms' negative news in crash risk. We employ three proxies for firms' negative information: Whether the firm's EPS is lower than analysts' consensus expectations (DEPS); whether the firm or its executive being penalized by the CSRC (Punish); and whether the firm was involved in lawsuits as a defendant (Lawsuit) during the past 6 months.

First, regression results in Table 4 show a positive regression coefficient of negative information $\left(D E P S_{i, b}\right.$ Punish $_{i, t}$ and Lawsuit $\left.t_{i, t}\right)$ and crash risk, indicating that the release of bad news significantly aggravates current crash risk. Second, the regression coefficients of cross terms between $E_{S O P}, t-1$ and DEPS ${ }_{i, t}$ (Punish $_{i, t}$ and Lawsuit $_{i, t}$ ) are significantly negative, indicating that previously announced ESOPs can alleviate crash risk caused by the outbreak of negative information. Results in Table 4 is consistent with the signaling effect that ESOPs send positive signals about firms' future value and build up investors' confidence in stock prices, which decrease the adverse effects of negative information on crash risk.

It is worth noting that the signaling effect in this paper is not entirely consistent with previous mainstream research on stock price crash risk which focuses on the concealment and subsequent concentrated outbreak of bad news (e.g., Kim et al. 2011a, 2011b; Piotroski et al. 2015). However, as found by Goldstein and Guembel (2008) and Chu and Fang (2016), crash risk describes the imbalance of stock price volatility between ascending and descending stages, and is manifested through investors' trading behaviors. Following this research, we compare the differences between ESOP firms and their matched ones on stock price performance and investors' trading behavior after the release of bad news and test the influence of these differences on the relationship of ESOPs and crash risk.

We define bad news as when a listed firm or its executive is penalized by the CSRC (Punish), and/or the firm is involved in lawsuits as a defendant (Lawsuit). Different from the regression results presented in Table 4, we drop DEPS from the bad news measurement if a firm's earnings per share (EPS) is formally disclosed in annual reports, which contain other information that affects stock price and investor behavior. We collect 1,291 cases where ESOP firms and their matched ones were involved in lawsuits as a defendant (Lawsuit) and 381 cases that listed firms or its executives were penalized by the CSRC (Punish). We drop observations in which two or more incidents of bad news were released in less than 3 months to control the mixed influence of different incidents of bad news. Finally, we obtain 1,421 observations of bad news, 706 from ESOP firms and the other 715 from matched samples. We define stock price performance as the cumulative abnormal returns adjusted by market line in the subsequent 5 days after bad news was released $[C A R(0,5)]$, and investors' behavior as firms' stock turnover in the 30 days (Stto) after the release of bad news. Stto is adjusted by the industry level to control the co-movement effect of sectors, which is a typical phenomenon in Chinese stock markets.

We then compare the difference of CAR $(0,5)$ and Stto between ESOP firms and their matched ones using the $t$-test method. Table 5 presents the results of the $t$-test.

Results in Table 5 show that there are significant differences between ESOP firms and matched ones in stock price performance and investors' trading behavior. 
Table 4 Signaling effect of ESOPs on crash risk

\begin{tabular}{|c|c|c|c|c|c|c|}
\hline \multirow[t]{2}{*}{ Variable } & \multicolumn{2}{|l|}{ DEPS } & \multicolumn{2}{|l|}{ Punish } & \multicolumn{2}{|l|}{ Lawsuit } \\
\hline & NCSKEW (1) & DUVOL (2) & NCSKEW (3) & DUVOL (4) & NCSKEW (5) & DUVOL (6) \\
\hline \multirow[t]{2}{*}{$\overline{E S O P}_{i, t-1} \times D E P S_{i, t}$} & $-0.002^{b}$ & $-0.002^{c}$ & & & & \\
\hline & $(-2.28)$ & $(-3.52)$ & & & & \\
\hline \multirow[t]{2}{*}{$E O P_{i, t-1} \times$ Punish $_{i, t}$} & & & $-0.008^{b}$ & $-0.015^{b}$ & & \\
\hline & & & $(-2.51)$ & $(-1.98)$ & & \\
\hline \multirow[t]{2}{*}{$\mathrm{ESOP}_{i, t-1} \times$ Lawsuit $_{i, t}$} & & & & & $-0.005^{c}$ & $-0.010^{b}$ \\
\hline & & & & & $(-3.01)$ & $(-2.27)$ \\
\hline \multirow[t]{2}{*}{$E S O P_{i, t-1}$} & $-0.027^{b}$ & $-0.04^{b}$ & $-0.027^{b}$ & $-0.044^{c}$ & $-0.023^{b}$ & $-0.035^{b}$ \\
\hline & $(-2.13)$ & $(-2.57)$ & $(-2.17)$ & $(-3.09)$ & $(-2.01)$ & $(-2.05)$ \\
\hline \multirow[t]{2}{*}{$D E P S_{i, t}$} & $0.002^{a}$ & $0.002^{a}$ & & & & \\
\hline & $(1.93)$ & $(1.68)$ & & & & \\
\hline \multirow[t]{2}{*}{ Punish $_{i, t}$} & & & $0.059^{b}$ & $0.019^{b}$ & & \\
\hline & & & $(1.91)$ & $(2.48)$ & & \\
\hline \multirow[t]{2}{*}{ Lawsuit $_{i, t}$} & & & & & $0.066^{\mathrm{a}}$ & $0.040^{c}$ \\
\hline & & & & & $(1.82)$ & (3.48) \\
\hline \multirow[t]{2}{*}{ Dturn $_{i, t-1}$} & 0.011 & 0.008 & 0.008 & 0.007 & 0.008 & 0.007 \\
\hline & $(1.47)$ & $(1.51)$ & $(1.09)$ & $(1.22)$ & $(1.11)$ & $(1.23)$ \\
\hline \multirow[t]{2}{*}{ Hret $_{i, t-1}$} & $0.725^{c}$ & $0.54^{c}$ & $0.723^{c}$ & $0.527^{c}$ & $0.724^{c}$ & $0.527^{c}$ \\
\hline & $(11.85)$ & $(11.21)$ & $(12.21)$ & $(11.21)$ & $(12.24)$ & $(11.21)$ \\
\hline \multirow[t]{2}{*}{ Sigma $_{i, t-1}$} & $-3.676^{a}$ & -1.761 & -2.902 & -1.239 & -3.092 & -1.343 \\
\hline & $(-1.70)$ & $(-1.10)$ & $(-1.38)$ & $(-0.79)$ & $(-1.47)$ & $(-0.86)$ \\
\hline \multirow[t]{2}{*}{$M B_{i, t-1}$} & $0.023^{c}$ & $0.011^{b}$ & $0.016^{c}$ & $0.009^{c}$ & $0.016^{c}$ & $0.009^{c}$ \\
\hline & $(3.67)$ & $(2.42)$ & (3.69) & $(2.90)$ & $(3.74)$ & $(2.93)$ \\
\hline \multirow[t]{2}{*}{ Size $_{i, t-1}$} & -0.004 & $-0.023^{a}$ & -0.012 & $-0.024^{b}$ & -0.012 & $-0.023^{a}$ \\
\hline & $(-0.26)$ & $(-1.83)$ & $(-0.75)$ & $(-1.97)$ & $(-0.75)$ & $(-1.96)$ \\
\hline \multirow[t]{2}{*}{$\operatorname{LeV}_{i, t-1}$} & $0.158^{\mathrm{a}}$ & 0.061 & 0.118 & 0.039 & 0.114 & 0.036 \\
\hline & $(1.91)$ & $(0.99)$ & $(1.50)$ & $(0.68)$ & $(1.46)$ & $(0.62)$ \\
\hline \multirow[t]{2}{*}{$R O A_{i, t-1}$} & $-0.033^{c}$ & $-0.034^{c}$ & $-0.028^{c}$ & $-0.031^{c}$ & $-0.027^{c}$ & $-0.03^{c}$ \\
\hline & $(-5.04)$ & $(-6.96)$ & $(-4.40)$ & $(-6.49)$ & $(-4.27)$ & $(-6.38)$ \\
\hline \multirow[t]{2}{*}{$D A_{i, t-1}$} & -0.127 & -0.085 & -0.158 & -0.113 & -0.163 & -0.116 \\
\hline & $(-1.16)$ & $(-1.05)$ & $(-1.49)$ & $(-1.44)$ & $(-1.53)$ & $(-1.48)$ \\
\hline \multirow[t]{2}{*}{$N_{C S K E W_{i, t-1}}$} & $0.093^{c}$ & & $0.09^{c}$ & & $0.09^{c}$ & \\
\hline & $(5.95)$ & & (5.88) & & $(5.87)$ & \\
\hline \multirow[t]{2}{*}{$D U V O L_{i, t-1}$} & & $0.105^{c}$ & & $0.103^{c}$ & & $0.103^{c}$ \\
\hline & & $(6.21)$ & & $(6.22)$ & & $(6.20)$ \\
\hline \multirow[t]{2}{*}{ Intercept } & 0.164 & $0.626^{b}$ & 0.304 & $0.615^{b}$ & 0.296 & $0.606^{b}$ \\
\hline & $(0.41)$ & $(2.09)$ & $(0.80)$ & $(2.18)$ & $(0.78)$ & $(2.15)$ \\
\hline Fix_ind & Yes & Yes & Yes & Yes & Yes & Yes \\
\hline Fix_time & Yes & Yes & Yes & Yes & Yes & Yes \\
\hline Adj-R $R^{2}$ & 0.1492 & 0.1771 & 0.1503 & 0.1768 & 0.1509 & 0.1773 \\
\hline No. of obs. & 4634 & 4634 & 4832 & 4832 & 4832 & 4832 \\
\hline
\end{tabular}

Notes. This table presents results of the relationship between ESOPs and crash risk when firms' negative information is disclosed, estimated by the equation:

CrashRisk $_{i, t}=a_{0}+a_{1} \times$ ESOP $_{i, t-1} \times$ Signal $_{i, t-1}+a_{2} \times$ ESOP $_{i, t-1}+a_{3} \times$ Signal $_{i, t-1}+a_{4} \times$ Control Variablest $_{t-1}+\varepsilon_{i, t}$,

The $t$-statistics, reported in parentheses, are based on standard errors clustered by both firm and time. Time and industry fixed effects are included. Here ${ }^{a},{ }^{b}$, and ${ }^{c}$ indicate statistical significance at the $10 \%, 5 \%$, and $1 \%$ levels, respectively 
Concretely, firms suffer a negative cumulative abnormal return of $15.3 \%$ in the 5 days after the release of bad news, while the negative cumulative abnormal return decreases to $12.6 \%$ if the firm had announced the adoption of an ESOP beforehand. The $2.7 \%$ difference (significant at the $1 \%$ level) in cumulative abnormal returns may change the distribution of stock returns and affect stock price crash risk. The release of bad news also causes a fire sale and increases the turnover ratio of stocks. The turnover ratio of stocks increases to an additional $78.1 \%$ compared to its industry level in the 30 days after the breakout of bad news, but it decreases to $47.7 \%$ if a firm had announced the adoption of an ESOP beforehand. The difference in stock turnover ratio (significant at the 1\% level) indicates that investors have more confidence in ESOP firms and are more cautious to sell ESOP stocks, which can also reduce stock price crash risk. In sum, Table 5 shows that the adoption of ESOPs does influence investors' trading behavior and the distribution of stock returns, which may change the level of stock price crash risk.

To further examine whether this influence is pronounced in the relationship between ESOPs and crash risk, we then test the mediation effect of CAR $(0,5)$ and Stto on the relationship between ESOPs and crash risk. Table 6 presents the results of these regressions.

Regression results in Table 6 show that the negative relationship between ESOPs and crash risk still exists when we reduce our research sample to firms experiencing bad news, in columns (1) and (6), which is the baseline fortesting the mediation effect. Regression results in columns $(2)$ and $(7)$ show that $\operatorname{CAR}(0,5)$ is negatively related to crash risk, which indicates that ESOP adoption may reduce crash risk through changing stock price performance, as ESOP adoption can decrease the negative cumulative abnormal returns caused by bad news (the result is presented in Table 5). Regression results in columns (3) and (8) show that the negative relationship between ESOPs and crash risk disappears when we add the variable $\operatorname{CAR}(0,5)$ into the regression of ESOP and crash, which further improves the mediation effective of $\operatorname{CAR}(0,5)$ on the relationship between ESOP and crash risk.

The regression results of Stto are similar as that of $\operatorname{CAR}(0,5)$. The release of bad news causes a fire sale, leads to a higher stock turnover ratio, and increases crash risk [in columns (4) and (9)]. The adoption of an ESOP can decrease the abnormal high stock turnover ratio (this result is presented in Table 5). When we add Stto into the regression equation, the negative relationship between ESOPs and crash disappears [in column (5)] or decreases [in column (10)]. This result can also improve the existence of the mediation effect.

In sum, Tables 5 and 6 further improve our understanding of how the signaling effect of ESOPs works: ESOPs send positive signals to capital markets that insiders are optimistic about the firms' future value, which helps enhance investors' confidence. If

Table 5 Stock price performance and investor trading behavior after negative information disclosure

\begin{tabular}{|c|c|c|c|c|c|c|}
\hline \multirow[t]{2}{*}{$\overline{\text { Variable }}$} & \multicolumn{2}{|c|}{ ESOP Firms (1) } & \multicolumn{2}{|c|}{ Matched Samples (2) } & \multicolumn{2}{|c|}{ Difference (1)-(2) } \\
\hline & Means & No. of obs. & Means & No. of obs. & Means & $t$-value \\
\hline$\overline{\operatorname{CAR}(0,5)}$ & -0.126 & 706 & -0.153 & 715 & $0.027^{\mathrm{a}}$ & $(8.33)$ \\
\hline Stto & 0.477 & 706 & 0.781 & 715 & $-0.304^{a}$ & (15.98) \\
\hline
\end{tabular}

Notes. This table presents the difference in price performance and investor trading behavior between ESOP firms and their matched ones after the disclosure of negative information using a $t$-test method $C A R(0,5)$ is the cumulative abnormal returns adjusted by market line in the 5 days after bad news is disclosed, which measures stock price performance. Stto is firms' stock turnover ratio in the 30 trading days after negative information disclosure to measure investor trading behavior. Here ${ }^{a}$ indicate statistical significance at the $1 \%$ levels 
Table 6 Mediation effect of CAR $(0,5)$ and Stto on the relationship between ESOPs and crash risk

\begin{tabular}{|c|c|c|c|c|c|c|c|c|c|c|}
\hline Variable & $\begin{array}{l}\text { NCSKEW } \\
\text { (1) }\end{array}$ & $\begin{array}{l}\text { NCSKEW } \\
(2)\end{array}$ & $\begin{array}{l}\text { NCSKEW } \\
\text { (3) }\end{array}$ & $\begin{array}{l}\text { NCSKEW } \\
\text { (4) }\end{array}$ & $\begin{array}{l}\text { NCSKEW } \\
\text { (5) }\end{array}$ & $\begin{array}{l}\text { DUVOL } \\
\text { (6) }\end{array}$ & $\begin{array}{l}\text { DUVOL } \\
\text { (7) }\end{array}$ & $\begin{array}{l}\text { DUVOL } \\
\text { (8) }\end{array}$ & $\begin{array}{l}\text { DUVOL } \\
\text { (9) }\end{array}$ & $\begin{array}{l}\text { DUVOL } \\
\text { (10) }\end{array}$ \\
\hline \multirow[t]{2}{*}{ Intercept } & $-1.968^{c}$ & $-1.324^{b}$ & $-1.321^{b}$ & $-2.187^{c}$ & $-2.189^{c}$ & -0.528 & -0.3 & -0.292 & $-0.654^{\mathrm{a}}$ & $-0.65^{\mathrm{a}}$ \\
\hline & $(-3.59)$ & $(-2.53)$ & $(-2.52)$ & $(-4.03)$ & $(-4.03)$ & $(-1.38)$ & $(-0.79)$ & $(-0.77)$ & $(-1.71)$ & $(-1.70)$ \\
\hline \multirow[t]{2}{*}{$E S O P_{i, t-1}$} & $-0.072^{c}$ & & -0.035 & & -0.019 & $-0.062^{b}$ & & -0.077 & & $-0.054^{\mathrm{a}}$ \\
\hline & $(-3.05)$ & & $(-0.79)$ & & $(-0.41)$ & $(-2.33)$ & & $(-1.41)$ & & $(-1.67)$ \\
\hline \multirow[t]{2}{*}{$\operatorname{CAR}(0,5)$} & & $-0.98^{c}$ & $-0.983^{c}$ & & & & $-0.343^{c}$ & $-0.349^{c}$ & & \\
\hline & & $(-15.54)$ & $(-15.56)$ & & & & $(-7.55)$ & $(-7.69)$ & & \\
\hline \multirow[t]{2}{*}{$S_{t t o}, t$} & & & & $0.336^{c}$ & $0.337^{c}$ & & & & $0.201^{c}$ & $0.199^{c}$ \\
\hline & & & & $(7.10)$ & (7.11) & & & & $(6.03)$ & (5.95) \\
\hline \multirow[t]{2}{*}{ Dturn $_{i, t-1}$} & -0.023 & -0.011 & -0.011 & -0.019 & -0.019 & -0.017 & -0.013 & -0.013 & -0.015 & -0.015 \\
\hline & $(-1.45)$ & $(-0.77)$ & $(-0.74)$ & $(-1.24)$ & $(-1.25)$ & $(-1.60)$ & $(-1.24)$ & $(-1.17)$ & $(-1.43)$ & $(-1.40)$ \\
\hline \multirow[t]{2}{*}{ Hret $_{i, t-1}$} & $0.182^{c}$ & $0.268^{c}$ & $0.266^{c}$ & $0.202^{c}$ & $0.203^{c}$ & $0.222^{c}$ & $0.257^{c}$ & $0.251^{c}$ & $0.235^{c}$ & $0.23^{c}$ \\
\hline & (3.81) & $(5.85)$ & (5.80) & $(4.28)$ & (4.29) & (6.33) & $(7.37)$ & $(7.21)$ & (6.74) & $(6.60)$ \\
\hline \multirow[t]{2}{*}{ Sigma $_{i, t-1}$} & $-20.149^{c}$ & $-20.094^{c}$ & $-20.142^{c}$ & $-19.008^{c}$ & $-18.979^{c}$ & $-12.7^{c}$ & $-12.348^{c}$ & $-12.513^{c}$ & $-11.938^{c}$ & $-12.063^{c}$ \\
\hline & $(-12.27)$ & $(-12.84)$ & $(-12.86)$ & $(-11.65)$ & $(-11.62)$ & $(-10.93)$ & $(-10.76)$ & $(-10.90)$ & $(-10.32)$ & $(-10.41)$ \\
\hline \multirow[t]{2}{*}{$M B_{i, t-1}$} & $0.032^{c}$ & $0.017^{b}$ & $0.018^{b}$ & $0.03^{c}$ & $0.03^{c}$ & $0.012^{b}$ & 0.005 & 0.007 & $0.01^{a}$ & $0.011^{\mathrm{a}}$ \\
\hline & (3.77) & $(2.12)$ & (2.18) & (3.65) & (3.59) & (2.03) & $(0.93)$ & $(1.15)$ & $(1.68)$ & $(1.84)$ \\
\hline \multirow[t]{2}{*}{ Size $_{i, t-1}$} & $0.099^{c}$ & $0.07^{c}$ & $0.07^{c}$ & $0.104^{c}$ & $0.104^{c}$ & $0.037^{b}$ & 0.025 & 0.026 & $0.039^{b}$ & $0.039^{b}$ \\
\hline & (3.98) & (2.94) & (2.96) & $(4.22)$ & $(4.21)$ & $(2.12)$ & $(1.47)$ & (1.52) & $(2.24)$ & $(2.28)$ \\
\hline \multirow[t]{2}{*}{$\operatorname{Lev}_{i, t-1}$} & 0.091 & -0.109 & -0.099 & -0.112 & -0.118 & $-0.246^{c}$ & $-0.344^{c}$ & $-0.32^{c}$ & $-0.39^{c}$ & $-0.371^{c}$ \\
\hline & $(0.70)$ & $(-0.88)$ & $(-0.79)$ & $(-0.85)$ & $(-0.89)$ & $(-2.70)$ & $(-3.82)$ & $(-3.54)$ & $(-4.23)$ & $(-4.00)$ \\
\hline \multirow[t]{2}{*}{$R O A_{i, t-1}$} & $-0.014^{c}$ & -0.008 & -0.007 & $-0.013^{b}$ & $-0.013^{b}$ & $-0.015^{c}$ & $-0.012^{c}$ & $-0.012^{c}$ & $-0.014^{c}$ & $-0.014^{c}$ \\
\hline & $(-2.83)$ & $(-1.58)$ & $(-1.56)$ & $(-2.55)$ & $(-2.56)$ & $(-4.16)$ & $(-3.57)$ & $(-3.51)$ & $(-4.00)$ & $(-3.97)$ \\
\hline \multirow[t]{2}{*}{$D A_{i, t-1}$} & -0.061 & -0.119 & -0.117 & -0.036 & -0.037 & 0.012 & -0.009 & -0.006 & 0.025 & 0.027 \\
\hline & $(-0.70)$ & $(-1.43)$ & $(-1.42)$ & $(-0.42)$ & $(-0.43)$ & $(0.20)$ & $(-0.15)$ & $(-0.11)$ & $(0.41)$ & $(0.44)$ \\
\hline \multirow[t]{2}{*}{$N_{C S K E W_{i, t-1}}$} & $0.124^{c}$ & $0.065^{c}$ & $0.067^{c}$ & $0.124^{c}$ & $0.123^{c}$ & & & & & \\
\hline & $(5.00)$ & $(2.75)$ & (2.82) & $(5.09)$ & (5.01) & & & & & \\
\hline \multirow[t]{2}{*}{ DUVOL $_{i, t-1}$} & & & & & & $0.045^{\mathrm{a}}$ & $0.069^{c}$ & $0.062^{b}$ & $0.042^{\mathrm{a}}$ & 0.038 \\
\hline & & & & & & $(1.80)$ & (2.78) & (2.51) & $(1.70)$ & $(1.50)$ \\
\hline Fix_ind & Yes & Yes & Yes & Yes & Yes & Yes & Yes & Yes & Yes & Yes \\
\hline Fix_time & Yes & Yes & Yes & Yes & Yes & Yes & Yes & Yes & Yes & Yes \\
\hline $\operatorname{Adj}-R^{2}$ & 0.1018 & 0.1827 & 0.1825 & 0.1199 & 0.1196 & 0.0715 & 0.0913 & 0.0931 & 0.0837 & 0.0844 \\
\hline No. of obs. & 1421 & 1421 & 1421 & 1421 & 1421 & 1421 & 1421 & 1421 & 1421 & 1421 \\
\hline
\end{tabular}

Notes. This table presents the regression results of the mediation effect of $\operatorname{CAR}(0,5)$ and Stto on the relationship between ESOPs and crash risk, estimated by regression equations system:

CrashRisk $_{i, t}=a_{0}+a_{1} \times$ ESOP $_{i, t-1}+a_{2} \times$ Control Variables $_{t-1}+\varepsilon_{i, t}$

CrashRisk $_{i, t}=a_{0}+a_{1} \times \operatorname{Car}(0,5) /$ Stto $_{i, t}+a_{2} \times$ Control Variables $_{t-1}+\varepsilon_{i, t}$

CrashRisk $_{i, t}=a_{0}+a_{1} \times$ ESOP $_{i, t-1}+a_{2} \times \operatorname{Car}(0,5) /$ Stto $_{i, t}+a_{3} \times$ Control Variables $_{t-1}+\varepsilon_{i, t}$

The $t$-statistics, reported in parentheses, are based on standard errors clustered by both firm and time. Time and industry fixed effects are included. Here ${ }^{a},{ }^{b}$, and ${ }^{c}$ indicate statistical significance at the $10 \%, 5 \%$, and $1 \%$ levels, respectively 
firms have bad news, investors will be more cautious selling stock. The change in investors' behavior will decrease negative cumulative abnormal returns and abnormal high stock turnover ratios caused by stock fire sales, and finally reduce crash risk.

The signaling effect of ESOPs may also work because participation in an ESOP may make employees more likely to release bad news. However, this hypothesis may be limited as employees also suffer from falling stock price caused by bad news. The motivation for employees to disclose firms' bad news is unclear in an ESOP firm.

We attribute this to the lock-in period for ESOPs. ESOPs in China usually contain a lock-in period at the time ESOP equities are offered to employees. The lock-in period is usually 12 months, and can reach up to 18 months, 24 months, or even 36 months in some ESOPs. Shares offered to employees cannot be traded during the lock-in period. During this time, employees are encouraged to disclose bad news about their firms for two reasons. First, employees will not suffer actual losses due to falling share prices within the lock-in period, as their shares cannot be traded. Share prices still have a chance to recover from negative shocks before the end of the lock-in period and employees' selling shares. Second, hoarded bad news may be disclosed after the lock-in period if not done by employees first, which will cause a sharp fall in share price. This will prevent employees from easily selling shares and employees may suffer larger losses.

The motivation for employees releasing bad news may weaken when the lock-in period ends. They may even help conceal bad news to maintain high share prices if they plan to sell shares in the near future.

Based on this analysis, we divide our research samples into two groups according to whether they were in or out of the lock-in period. We then test the influence of ESOPs on crash risk in these two subsamples separately using regression Eq. (5).

We also test the difference of ESOPs' effect on crash risk during and after the lock-in period using the difference-in-difference (DID) method. The estimate regression equation is:

$$
\begin{gathered}
\text { CrashRisk }_{i, t}=\alpha_{0}+\alpha_{1} \times \text { ESOP }_{i, t-1} \times \text { Block }_{i, t}+\alpha_{2} \times \text { ESOP }_{i, t-1} \\
+\alpha_{3} \times \text { Block }_{i, t}+\alpha_{4} \times \text { Control }_{\text {Variables }}+1+\varepsilon_{i, t},
\end{gathered}
$$

where $B l o c k_{i, t}$ is a dummy variable measure whether ESOP shares are still within the lock-in period. It is valued 1 if ESOP shares are still within the lock-in period and 0 otherwise. Table 7 presents the results of the regressions.

Regression results in columns (1) and (2) show that an ESOP is negatively related to crash risk, which indicates that employees are more likely to disclose bad news to avoid the risk of stock price decline within a lock-in period. The significance of the negative relationship between ESOP and crash risk is reduced (regression result 3), and even disappears (regression result 4) after the lock-in period when employees no longer have strong motivations to disclose a firm's bad news if they are planning to or already have sold their shares. The cross terms in columns (5) and (6) are negatively related to crash risk, meaning that there are significant differences in the relationship between ESOPs and crash risk around the end of the lock-in period.

In sum, regression results in Table 7 indicate that employees are more motivated to disclose bad news to avoid future stock price crash risk when ESOP stocks are still within a lock-in period, and this motivation decreases as the lock-in period 
ends. This may be another way for the signaling effect to work: ESOP adoption indicates that employees are more motivated to disclose firms' bad news. Investing in these firms is less risky. This will also enhance investors' confidence and reduce crash risk.

However, the wide-spread implementation of ESOPs in China has only recently started, and most ESOPs are still within their lock-in period. As time goes on, and more and more ESOP shares are unlocked, employees' motivation to disclose firms' bad news will change, and the relationship between ESOPs and crash risk may also change.

\section{Additional analysis of the signaling effect}

Previous research has found that firms adopting ESOPs generally are quite different, and that the details of ESOPs are also varied, that is, ESOPs are heterogeneous. It is therefore important to consider the heterogeneity of ESOPs in examining the relationship between ESOPs and crash risk. Examining the effect of ESOP characteristics on crash risk will also help further verify the signaling mechanism of ESOPs. Therefore, in considering ESOP heterogeneity, we examine the different influences of specific characteristics of ESOPs on stock price crash risk from three aspects: ESOP leverage, ESOP scale, and ESOP price.

\section{ESOP leverage and crash risk}

One of the important characteristics of ESOPs is whether or not the funds used in the ESOP come from leveraged financing and the proportion of leverage. Leverage in an ESOP is related to tax avoidance (Chaplinsky and Niehaus 1990; Shackelford 1991) and anti-takeover measures (Brecher et al. 1983) and influences firm value and shareholders' wealth (Chang 1990). From the perspective of the signaling effect, leveraged funds often have the priority claim in leveraged ESOPs, while employees' own funds have a residual claim. As a well-known incentive system, ESOPs link employees' interests to firm value. Employees will not only share in stock price gains but also risk stock price losses. The risk of loss from falling share prices is often magnified by the priority claim of leveraged funds, which will affect the decision of employees to participate in the stock ownership plan and its signaling effect. In sum, we predict that leveraged ESOPs send a stronger signal to capital markets and are more likely to decrease crash risk, compared with non-leveraged ESOPs.

To verify these differences, we employ two variables to proxy ESOP leverage characteristics: Whether the ESOP includes leveraged funds (Dum_Lev_ESOP $i, t-1)$, and the leverage ratio of the ESOP $\left(L e v_{-} E S O P_{i, t-1}\right)$. Then we run the following equation to further verify the influence of ESOPs on stock price crash risk.

$$
\begin{gathered}
\text { CrashRisk }_{i, t}=\alpha_{0}+\alpha_{1} \times \text { Dum_lev_ESOP } P_{i, t-1}\left(\text { Lev_ESOP }_{i, t-1}\right)+\alpha_{2} \times \text { ESOP }_{i, t-1} \\
+\alpha_{3} \times \text { Control Variables } t-1+\varepsilon_{i, t} .
\end{gathered}
$$

Table 8 presents the effect of ESOP leverage on crash risk. Results show that the negative impact of ESOPs on stock price crash risk still exists after considering the leverage factor, but compared with non-leveraged ESOPs, leveraged ESOPs do not reduce 
Table 7 Lock-in period, ESOP and crash risk

\begin{tabular}{|c|c|c|c|c|c|c|}
\hline \multirow[t]{2}{*}{ Variable } & \multicolumn{2}{|c|}{ Lock-in period } & \multicolumn{2}{|l|}{ After lock-in } & \multicolumn{2}{|l|}{ DID test } \\
\hline & NCSKEW (1) & DUVOL (2) & NCSKEW (3) & DUVOL (4) & NCSKEW (5) & DUVOL (6) \\
\hline \multirow[t]{2}{*}{ Intercept } & $0.726^{b}$ & $0.837^{c}$ & 0.975 & 0.603 & 0.142 & 0.372 \\
\hline & $(2.01)$ & $(3.11)$ & $(0.57)$ & $(-0.50)$ & $(0.24)$ & $(0.85)$ \\
\hline$E S O P_{i, t-1}$ & & & & & $-0.033^{\mathrm{a}}$ & $-0.039^{b}$ \\
\hline$\times$ Block $_{i, t}$ & & & & & $(-1.73)$ & $(-2.16)$ \\
\hline \multirow[t]{2}{*}{$E S O P_{i, t-1}$} & $-0.036^{c}$ & $-0.046^{c}$ & $-0.043^{\mathrm{a}}$ & -0.288 & -0.463 & -0.361 \\
\hline & $(-2.68)$ & $(-2.92)$ & $(-1.92)$ & $(-1.54)$ & $(-1.45)$ & $(-1.54)$ \\
\hline \multirow[t]{2}{*}{ Block $k_{i, t}$} & & & & & $-0.003^{b}$ & $-0.002^{a}$ \\
\hline & & & & & $(-2.01)$ & $(-1.76)$ \\
\hline \multirow[t]{2}{*}{ Dturn $_{i, t-1}$} & 0.001 & 0.005 & $0.108^{c}$ & 0.04 & 0.007 & 0.007 \\
\hline & $(0.06)$ & $(0.61)$ & $(2.70)$ & $(1.39)$ & $(0.72)$ & $(0.87)$ \\
\hline \multirow[t]{2}{*}{ Hret $_{i, t-1}$} & $0.756^{c}$ & $0.556^{c}$ & $1.304^{c}$ & $0.824^{c}$ & $0.823^{c}$ & $0.592^{c}$ \\
\hline & $(12.97)$ & (11.95) & $(3.81)$ & $(2.93)$ & $(10.65)$ & $(9.72)$ \\
\hline \multirow[t]{2}{*}{ Sigma $_{i, t-1}$} & -1.197 & -0.1 & -6.411 & -1.808 & -0.922 & -0.77 \\
\hline & $(-0.57)$ & $(-0.06)$ & $(-0.74)$ & $(-0.29)$ & $(-0.34)$ & $(-0.38)$ \\
\hline \multirow[t]{2}{*}{$M B_{i, t-1}$} & $0.026^{c}$ & $0.016^{\mathrm{b}}$ & 0.052 & 0.027 & $0.028^{c}$ & $0.017^{c}$ \\
\hline & $(3.08)$ & $(2.51)$ & $(1.38)$ & $(1.01)$ & $(3.34)$ & $(2.80)$ \\
\hline \multirow[t]{2}{*}{ Size $_{i, t-1}$} & $-0.031^{b}$ & $-0.033^{c}$ & -0.037 & -0.032 & -0.021 & -0.025 \\
\hline & $(-2.01)$ & $(-2.87)$ & $(-0.50)$ & $(-0.60)$ & $(-0.97)$ & $(-1.58)$ \\
\hline \multirow[t]{2}{*}{$\operatorname{Lev}_{i, t-1}$} & 0.103 & 0.026 & 0.387 & 0.246 & 0.058 & -0.073 \\
\hline & $(1.28)$ & $(0.44)$ & $(1.04)$ & $(0.94)$ & $(0.53)$ & $(-0.92)$ \\
\hline \multirow[t]{2}{*}{$R O A_{i, t-1}$} & $-0.022^{c}$ & $-0.026^{c}$ & $-0.067^{b}$ & $-0.063^{c}$ & $-0.038^{c}$ & $-0.035^{c}$ \\
\hline & $(-3.33)$ & $(-5.41)$ & $(-2.38)$ & $(-3.16)$ & $(-4.44)$ & $(-5.49)$ \\
\hline \multirow[t]{2}{*}{$D A_{i, t-1}$} & -0.158 & -0.111 & -0.679 & -0.448 & -0.21 & -0.123 \\
\hline & $(-1.45)$ & $(-1.37)$ & $(-1.39)$ & $(-1.30)$ & $(-1.42)$ & $(-1.13)$ \\
\hline \multirow[t]{2}{*}{ NCSKEW $W_{i, t-1}$} & $0.095^{c}$ & & 0.079 & & $0.062^{c}$ & \\
\hline & (5.96) & & $(1.28)$ & & $(2.98)$ & \\
\hline \multirow[t]{2}{*}{ DUVOL $L_{i, t-1}$} & & $0.107^{c}$ & & 0.111 & & $0.09^{c}$ \\
\hline & & $(6.27)$ & & $(1.49)$ & & $(4.00)$ \\
\hline Fix_ind & Yes & Yes & Yes & Yes & Yes & Yes \\
\hline Fix_time & Yes & Yes & Yes & Yes & Yes & Yes \\
\hline $\operatorname{Adj}-R^{2}$ & 0.1495 & 0.1777 & 0.1292 & 0.11 & 0.1623 & 0.1875 \\
\hline No. of obs. & 4517 & 4517 & 315 & 315 & 4832 & 4832 \\
\hline
\end{tabular}

Notes. This table presents regression results of the relationship during and after an ESOP's lock-inperiod. Results (1) to (4) are estimated by regression equation:

CrashRisk $_{i, t}=a_{0}+a_{1} \times$ ESOP $_{i, t-1}+a_{2} \times$ Control Variables $_{t-1}+\varepsilon_{i, t}$

Results (5) and (6) are estimated by regression equation

CrashRisk $_{i, t}=a_{0}+a_{1} \times$ ESOP $_{i, t-1} \times$ Block $_{i, t}+a_{2} \times$ ESOP $_{i, t-1}+a_{3} \times$ Block $_{i, t-1}+a_{4} \times$ Control Variables $_{t-1}+\varepsilon_{i, t}$

The $t$-statistics, reported in parentheses, are based on standard errors clustered by both firm and time. Time and industry

fixed effects are included. Here ${ }^{a},{ }^{b}$, and ${ }^{c}$ indicate statistical significance at the $10 \%, 5 \%$, and $1 \%$ levels, respectively

crash risk and sometimes even increase it, indicating a weaker effect of leveraged ESOPs on reducing stock price crash risk.

However, the regression results in Table 8 conflict with the signaling mechanism to some extent. The signaling effect supposes that the announcement of an ESOP indicates positive signals about a firm's value and reduces the influence of negative news on stock price. If ESOPs do send positive signals, leveraged ESOPs, in which 
participants take more risks, absolutely have stronger signaling effects and should be more helpful in reducing crash risk.

Results in Table 8 do not deny the signal effect completely. The positive relationship of ESOP leverage to crash risk maybe caused by specific signals from leveraged ESOPs under particular market situations. In June 2015, 1 year after China's ESOP system was officially put into practice, the capital markets suffered huge fluctuations and the stock prices of many leveraged ESOP firms fell below the warning line or even the liquidation line. Employees involved in leveraged ESOPs did not make extra gains but suffered losses because of compulsory liquidation pressure of leveraged ESOPs. As well, the fact that share prices fell to the liquidation line sent additional negative signals to the market: The ESOP would be forced to liquidate and trigger a continuous stock price crash. With this in mind, investors accelerated the sale of shares and further exacerbated stock price crash risk. ${ }^{1}$ Therefore, leveraged ESOPs in this situation do not help enhance market confidence, but exacerbate stock price volatility and heighten crash risk from liquidation expectations.

To test the hypothesis above, combined with the huge fluctuations of the China Ashare markets in 2015, we first divide our sample period into three sub-samples according to stock market index returns: pre-disaster (samples before June 2015), in-disaster (samples from June 2015 to October 2015) and post-disaster (samples after October 2015). Then we run Eq. (8) on these three sub samples respectively. The regression results are presented in Table 9.

Table 9 shows that the positive relationship between ESOP leverage and crash risk is not caused by the negative signaling effect of leveraged ESOPs but by a specific market situation. Before June 2015, leveraged ESOPs did not result in increased crash risk (as shown in regression results 1 to 4 in Table 8). However, starting from June 2015, China's stock markets suffered drastic fluctuations and stock prices fell rapidly over a short period. It is possible that investors sold their stocks early to avoid losses caused by compulsory liquidation, which eventually increased crash risk. In sum, the positive relationship between ESOP leverage and crash risk is caused by stock dumping due to forced liquidation rather than the signaling effect of leveraged ESOPs.

It should be noted that the sharp price fall in China A-shares came to an end in October 2015 and then started to turn up. However, further analyses show that the increasing effect of leveraged ESOPs on price crash risk still existed even though the stock market started to recover. The reasons may be as follows: On the one hand, investors still had no confidence in leveraged ESOPs due to their recent experiences with the crash; on the other hand, a "deleveraging" policy had been introduced and was being refined by Chinese government at the end of 2015. The interpretations and expectations of the deleveraging policies and aversion to leveraging may have contributed to investors' pessimism about leveraged ESOPs.

Meanwhile, the regression results 1 to 4 in Table 9 show that leveraged ESOPs neither increased nor decreased crash risk before June 2015. We suppose this is due to the

\footnotetext{
${ }^{1}$ In reality, mandatory liquidation of ESOPs rarely occurs even if the share price falls below the liquidation line due to the voluntary suspension of the company and opposition from financial institutions. However, leveraged ESOPs are new to the Chinese capital markets. The expectations that ESOPs will be forced to liquidate when the stock price falls below the liquidation line are reasonable according to established rules.
} 
Table 8 Leveraged ESOPs and crash risk

\begin{tabular}{|c|c|c|c|c|}
\hline Variable & NCSKEW (1) & NCSKEW (2) & DUVOL (3) & DUVOL (4) \\
\hline \multirow[t]{2}{*}{ Dum_Lev_ESOP ${ }_{i, t-1}$} & $0.078^{c}$ & & $0.028^{b}$ & \\
\hline & $(2.76)$ & & $(2.31)$ & \\
\hline \multirow[t]{2}{*}{$L_{e v \_} E S O P_{i, t-1}$} & & $0.018^{b}$ & & $0.008^{a}$ \\
\hline & & $(2.18)$ & & $(1.95)$ \\
\hline \multirow[t]{2}{*}{$E S O P_{i, t-1}$} & $-0.061^{b}$ & $-0.039^{\mathrm{a}}$ & $-0.05^{c}$ & $-0.044^{c}$ \\
\hline & $(-2.52)$ & $(-1.82)$ & $(-2.80)$ & $(-2.76)$ \\
\hline \multirow[t]{2}{*}{ Dturn $_{i, t-1}$} & 0.008 & 0.008 & 0.007 & 0.007 \\
\hline & (1.03) & $(1.04)$ & $(1.27)$ & $(1.28)$ \\
\hline \multirow[t]{2}{*}{ Hret $_{i, t-1}$} & $0.704^{c}$ & $0.703^{c}$ & $0.515^{c}$ & $0.514^{c}$ \\
\hline & $(11.82)$ & (11.79) & $(10.89)$ & $(10.87)$ \\
\hline \multirow[t]{2}{*}{ Sigma $_{i, t-1}$} & -2.824 & -2.769 & -1.034 & -1.015 \\
\hline & $(-1.35)$ & $(-1.32)$ & $(-0.66)$ & $(-0.65)$ \\
\hline \multirow[t]{2}{*}{$M B_{i, t-1}$} & $0.016^{c}$ & $0.016^{c}$ & $0.009^{c}$ & $0.009^{c}$ \\
\hline & (3.74) & $(3.71)$ & $(2.87)$ & $(2.85)$ \\
\hline \multirow[t]{2}{*}{ Size $_{i, t-1}$} & -0.009 & -0.011 & $-0.021^{a}$ & $-0.022^{\mathrm{a}}$ \\
\hline & $(-0.58)$ & $(-0.67)$ & $(-1.79)$ & $(-1.84)$ \\
\hline \multirow[t]{2}{*}{$\operatorname{Lev}_{i, t-1}$} & 0.113 & 0.12 & 0.036 & 0.039 \\
\hline & $(1.45)$ & $(1.54)$ & $(0.63)$ & $(0.67)$ \\
\hline \multirow[t]{2}{*}{$R O A_{i, t-1}$} & $-0.029^{c}$ & $-0.029^{c}$ & $-0.031^{c}$ & $-0.031^{c}$ \\
\hline & $(-4.6)$ & $(-4.61)$ & $(-6.57)$ & $(-6.57)$ \\
\hline \multirow[t]{2}{*}{$D A_{i, t-1}$} & -0.134 & -0.136 & -0.106 & -0.106 \\
\hline & $(-1.26)$ & $(-1.28)$ & $(-1.34)$ & $(-1.35)$ \\
\hline \multirow[t]{2}{*}{$N_{C S K E W_{i, t-1}}$} & $0.107^{c}$ & $0.108^{c}$ & & \\
\hline & $(6.81)$ & $(6.83)$ & & \\
\hline \multirow[t]{2}{*}{$D_{U V O} L_{i, t-1}$} & & & $0.119^{c}$ & $0.118^{c}$ \\
\hline & & & $(7.00)$ & $(6.99)$ \\
\hline \multirow[t]{2}{*}{ Intercept } & 0.273 & 0.311 & $0.569^{b}$ & $0.582^{b}$ \\
\hline & $(0.72)$ & $(0.82)$ & $(2.02)$ & $(2.06)$ \\
\hline Fix_ind & Yes & Yes & Yes & Yes \\
\hline Fix_time & Yes & Yes & Yes & Yes \\
\hline Adj-R $R^{2}$ & 0.1564 & 0.1559 & 0.1802 & 0.1802 \\
\hline No. of obs. & 4832 & 4832 & 4832 & 4832 \\
\hline
\end{tabular}

Notes. This table presents the influence of ESOP leverage on stock price crash risk. The empirical test equation is: CrashRisk $_{i, t}=a_{0}+a_{1} \times$ Dum_lev_ESOP $_{i, t-1}\left(\right.$ Lev_ESOP $\left._{i, t-1}\right)+a_{2} \times$ ESOP $_{i, t-1}+a_{3} \times$ Control Variables $_{t-1}+\varepsilon_{i, t}$ The $t$-statistics, reported in parentheses, are based on standard errors clustered by both firm and time. Time and industry fixed effects are included. Here ${ }^{a},{ }^{b}$, and ${ }^{c}$ indicate statistical significance at the $10 \%, 5 \%$, and $1 \%$ levels, respectively

market's limited recognition of ESOPs as they were still new at that time. We may need longer to reach a better understanding of leveraged ESOPs and their signaling effect, especially in China's capital markets where individuals account for the majority of investors. On the other hand, unlike firms' other decisions, ESOPs cannot be compared horizontally between different firms. As employees are subordinate to particular companies, they cannot directly decide the leverage ratio of an ESOP or choose among different stock ownership plans. Therefore, participation in a firm's ESOP can only indicate that the firm is "good," but participation in a leveraged ESOPs does not mean the firm is "better." This may also explain why leveraged ESOPs cannot further reduce crash risk. 


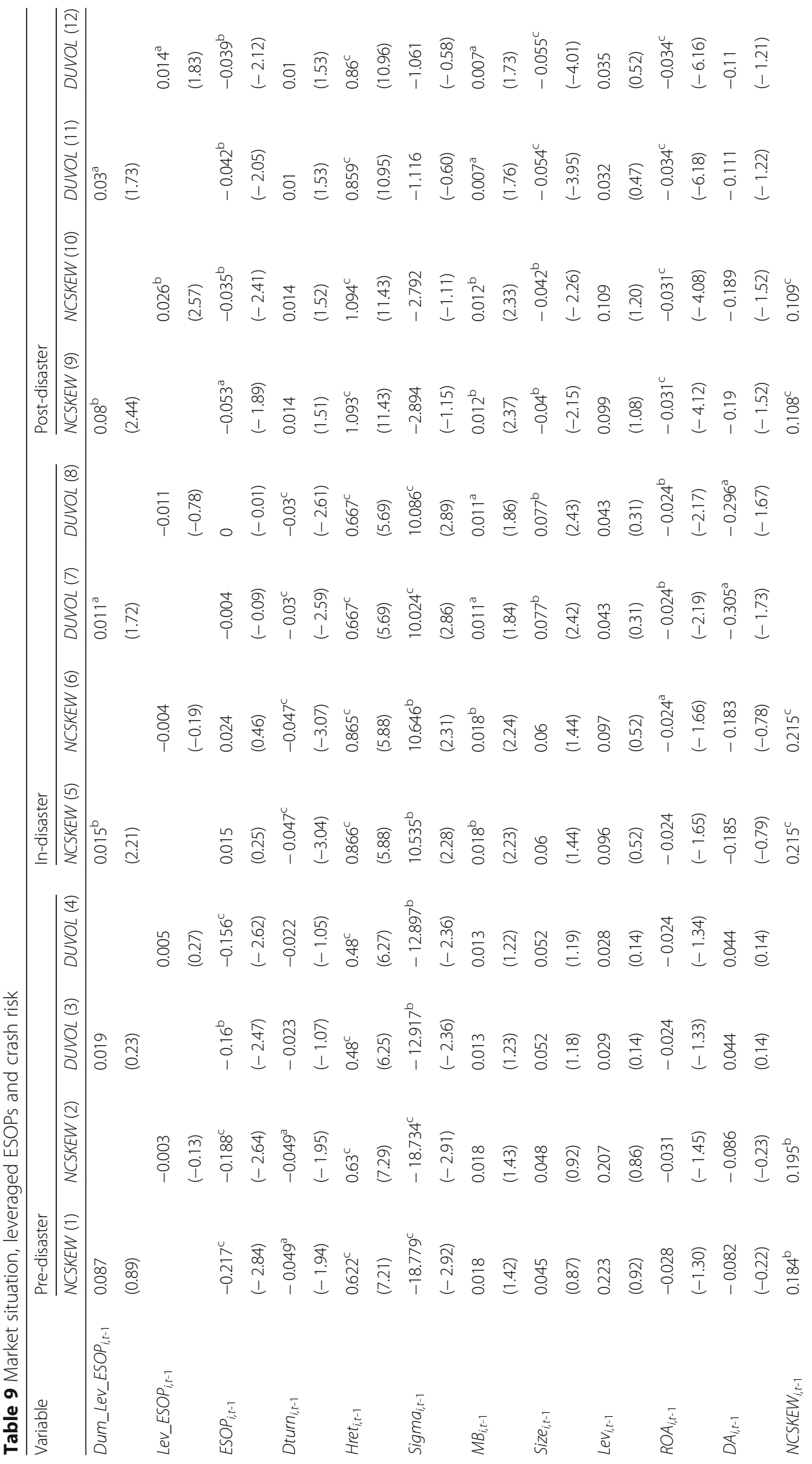




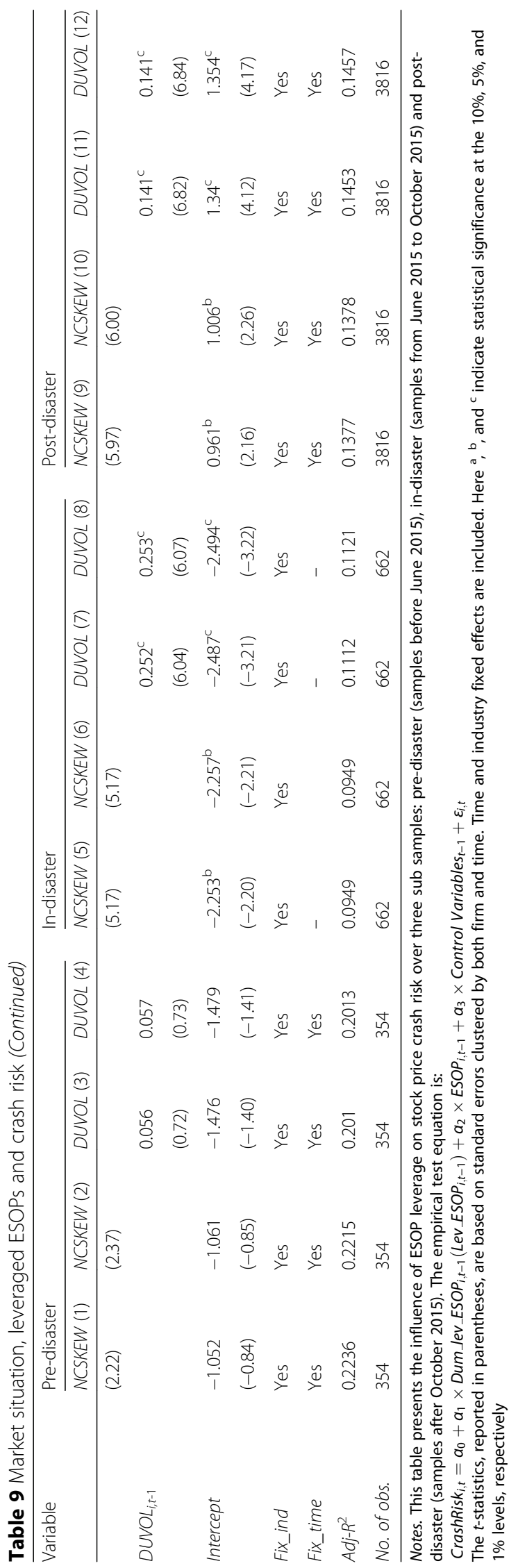




\section{ESOP scale and crash risk}

Another important characteristic of ESOPs is the stock ownership size. In terms of signaling effects, larger-sized ESOPs require employees to pay more money or assume higher risks through leveraged financing, thus sending a more convincing signal to the market that insiders are optimistic about a firm's value.

To examine the influence of ESOP size on crash risk, we employ two variables: the natural logarithm of total funds (both employees' own money and funds from leveraged financing are included) invested in an ESOP (Size_ESOP) and the proportion of employee stock ownership to total share capital (Stock_ESOP). Then we examine the influence of ESOP scale on crash risk using the following equation.

$$
\begin{aligned}
\text { CrashRisk }_{i, t}=\alpha_{0} & +\alpha_{1} \times \text { Size_ESOP } P_{i, t-1}\left(\text { Stock_ESOP }_{i, t-1}\right)+\alpha_{2} \times \text { ESOP }_{i, t-1} \\
& +\alpha_{3} \times \text { Control Variables } \\
t-1 & +\varepsilon_{i, t} .
\end{aligned}
$$

The regression results in Table 10 first show that larger-sized ESOPs generally contribute more to the reduction of stock price crash risk. Meanwhile, comparing the regression results of Size_ESOP $P_{i, t-1}$ and Stock_ESOP $P_{i,-1}$, we can conclude that investors consider the relative size of ESOPs (Stock_ESOP ${ }_{i, t-1}$ ) more important than the absolute capital size $\left(\right.$ Size_ESOP $\left._{i, t-1}\right)$. This is reasonable as the capital size of an ESOP is often related to the firm's size. For large firms, there are more employees and every $1 \%$ share corresponds to more stocks and more money to purchase them. Thus, the capital size of the ESOP does not send any additional signals of insiders' opinions.

\section{ESOP price and crash risk}

Stock price is also an important characteristic of ESOPs. First of all, stock price constitutes the cost of employee participation in an ESOP and directly determines future returns. Moreover, stock price reflects, to some extent, insiders' estimation of firm value, which is also important in signal sending. Therefore, the ESOP stock price may influence crash risk.

To examine the influence of ESOP price on crash risk, we use two variables to measure ESOP price: the estimated share price disclosed in the firm's "ESOP draft" (Price_ESOP ${ }_{i, t-1}$ ), and the ratio of Price_ESOP ${ }_{i, t-1}$ to the closing price on the ESOP announcement day $\left(R_{-}\right.$Price_ESOP $\left.P_{i, t-1}\right)$.

Then we run the following equation and report our findings in Table 11.

$$
\begin{aligned}
\text { CrashRisk }_{i, t}=\alpha_{0} & +\alpha_{1} \times \text { Price ESOP } \\
& +\alpha_{3, t-1} \times \text { Control } \text { Variables }_{t-1}+\varepsilon_{i, t} .
\end{aligned}
$$

The regression results in Table 11 show that when measured by the absolute price (Price_ESOP ${ }_{i, t-1}$ ), the regression coefficients of the share price are significant and positive. The higher the share price, the higher the firm's crash risk. The regression coefficient between relative ESOP price $\left(R_{-}\right.$Price_ESOP $\left.P_{i, t-1}\right)$ and crash risk is not significant.

Results in Table 11 are also inconsistent with the signaling effects. If ESOPs reduce crash risk by sending positive signals to capital markets, a higher share price would seem to suggest stronger insider confidence, reducing crash risk rather than increasing it. 
Table 10 ESOP scale and crash risk

\begin{tabular}{|c|c|c|c|c|}
\hline Variable & NCSKEW (1) & NCSKEW (2) & DUVOL (3) & DUVOL (4) \\
\hline \multirow[t]{2}{*}{ Size_ESOP ${ }_{i, t-1}$} & -0.003 & & -0.004 & \\
\hline & $(-0.38)$ & & $(-0.62)$ & \\
\hline \multirow[t]{2}{*}{ Stock_ESOP $P_{i, t-1}$} & & $-0.003^{c}$ & & -0.006 \\
\hline & & $(-2.37)$ & & $(-4.03)$ \\
\hline \multirow[t]{2}{*}{$E S O P_{i, t-1}$} & $-0.054^{c}$ & $-0.031^{c}$ & $-0.004^{b}$ & $-0.038^{c}$ \\
\hline & $(-2.71)$ & $(-4.24)$ & $(-2.08)$ & $(-3.03)$ \\
\hline \multirow[t]{2}{*}{ Dturn $_{i, t-1}$} & 0.008 & 0.008 & 0.007 & 0.007 \\
\hline & $(1.02)$ & $(1.03)$ & $(1.27)$ & $(1.27)$ \\
\hline \multirow[t]{2}{*}{ Hret $_{i, t-1}$} & $0.705^{c}$ & $0.705^{c}$ & $0.515^{c}$ & $0.515^{c}$ \\
\hline & $(11.82)$ & $(11.81)$ & $(10.91)$ & (10.89) \\
\hline \multirow[t]{2}{*}{ Sigma $_{i, t-1}$} & -2.79 & -2.779 & -1.02 & -1.022 \\
\hline & $(-1.33)$ & $(-1.33)$ & $(-0.65)$ & $(-0.66)$ \\
\hline \multirow[t]{2}{*}{$M B_{i, t-1}$} & $0.016^{c}$ & $0.016^{c}$ & $0.009^{c}$ & $0.009^{c}$ \\
\hline & (3.73) & $(3.76)$ & $(2.89)$ & $(2.87)$ \\
\hline \multirow[t]{2}{*}{ Size $_{i, t-1}$} & -0.012 & -0.011 & $-0.021^{a}$ & $-0.022^{\mathrm{a}}$ \\
\hline & $(-0.73)$ & $(-0.67)$ & $(-1.73)$ & $(-1.84)$ \\
\hline \multirow[t]{2}{*}{$\operatorname{Lev}_{i, t-1}$} & 0.121 & 0.121 & 0.04 & 0.039 \\
\hline & $(1.55)$ & $(1.56)$ & $(0.70)$ & $(0.68)$ \\
\hline \multirow[t]{2}{*}{$R O A_{i, t-1}$} & $-0.03^{c}$ & $-0.03^{c}$ & $-0.031^{c}$ & $-0.031^{c}$ \\
\hline & $(-4.65)$ & $(-4.62)$ & $(-6.55)$ & $(-6.59)$ \\
\hline \multirow[t]{2}{*}{$D A_{i, t-1}$} & -0.135 & -0.135 & -0.106 & -0.106 \\
\hline & $(-1.27)$ & $(-1.28)$ & $(-1.34)$ & $(-1.35)$ \\
\hline \multirow[t]{2}{*}{ NCSKEW $_{i, t-1}$} & $0.108^{c}$ & $0.108^{c}$ & & \\
\hline & $(6.88)$ & (6.88) & & \\
\hline \multirow[t]{2}{*}{ DUVOL $_{i, t-1}$} & & & $0.119^{c}$ & $0.119^{c}$ \\
\hline & & & $(7.02)$ & $(7.01)$ \\
\hline \multirow[t]{2}{*}{ Intercept } & 0.342 & 0.317 & $0.561^{b}$ & $0.586^{b}$ \\
\hline & $(0.89)$ & $(0.84)$ & $(1.97)$ & $(2.08)$ \\
\hline Fix_ind & Yes & Yes & Yes & Yes \\
\hline Fix_time & Yes & Yes & Yes & Yes \\
\hline Adj-R $R^{2}$ & 0.1551 & 0.1551 & 0.1799 & 0.1799 \\
\hline No. of obs. & 4832 & 4832 & 4832 & 4832 \\
\hline
\end{tabular}

Notes. This table presents the influence of ESOP scale on stock price crash risk. The empirical test equation is: CrashRisk $_{i, t}=a_{0}+a_{1} \times$ Size_ESOP $_{i, t-1}\left(\right.$ Stock_ESOP $\left._{i, t-1}\right)+a_{2} \times$ ESOP $_{i, t-1}+a_{3} \times$ Control Variables $_{t-1}+\varepsilon_{i, t}$ The $t$-statistics, reported in parentheses, are based on standard errors clustered by both firm and time. Time and industry fixed effects are included. Here ${ }^{a},{ }^{b}$, and ${ }^{c}$ indicate statistical significance at the $10 \%, 5 \%$, and $1 \%$ levels, respectively

We attribute these contradictory results to the particular market situation during the 2015 crash. As before, we divide our sample period into three sub-samples and run Eq. (10) respectively. We find similar results to 5.3.1. We do not present this table in the paper to focus on our main findings.

\section{Other tests}

Tests on the signaling effect of ESOPs show that employees participating in ESOPs are more motivated to disclose firms' bad news. Does this affect executives' behavior and 
Table 11 ESOP price and crash risk

\begin{tabular}{|c|c|c|c|c|}
\hline Variable & NCSKEW (1) & NCSKEW (2) & DUVOL (3) & DUVOL (4) \\
\hline \multirow[t]{2}{*}{ Price_ESOP $P_{i, t-1}$} & $0.002^{\mathrm{a}}$ & & 0.001 & \\
\hline & $(1.70)$ & & $(1.17)$ & \\
\hline \multirow[t]{2}{*}{ R_Price_ESOP ${ }_{i, t-1}$} & & -0.039 & & -0.033 \\
\hline & & $(-1.34)$ & & $(-1.52)$ \\
\hline \multirow[t]{2}{*}{$E S O P_{i, t-1}$} & $-0.057^{b}$ & $-0.011^{c}$ & $-0.054^{c}$ & $-0.015^{c}$ \\
\hline & $(-2.06)$ & $(-3.05)$ & $(-2.63)$ & $(-5.70)$ \\
\hline \multirow[t]{2}{*}{ Dturn $_{i, t-1}$} & 0.008 & 0.007 & 0.007 & 0.007 \\
\hline & $(1.03)$ & $(0.99)$ & $(1.27)$ & $(1.22)$ \\
\hline \multirow[t]{2}{*}{ Hret $_{i, t-1}$} & $0.705^{c}$ & $0.709^{c}$ & $0.514^{c}$ & $0.518^{c}$ \\
\hline & $(11.82)$ & (11.88) & (10.88) & $(10.96)$ \\
\hline \multirow[t]{2}{*}{ Sigma $_{i, t-1}$} & -2.931 & -2.697 & -1.103 & -0.942 \\
\hline & $(-1.40)$ & $(-1.29)$ & $(-0.71)$ & $(-0.60)$ \\
\hline \multirow[t]{2}{*}{$M B_{i, t-1}$} & $0.015^{c}$ & $0.016^{c}$ & $0.009^{c}$ & $0.009^{c}$ \\
\hline & (3.63) & (3.73) & $(2.79)$ & $(2.86)$ \\
\hline \multirow[t]{2}{*}{ Size $_{i, t-1}$} & -0.009 & -0.012 & $-0.021^{\mathrm{a}}$ & $-0.023^{\mathrm{a}}$ \\
\hline & $(-0.54)$ & $(-0.72)$ & $(-1.75)$ & $(-1.89)$ \\
\hline \multirow[t]{2}{*}{$\operatorname{Lev}_{i, t-1}$} & 0.113 & 0.121 & 0.035 & 0.039 \\
\hline & $(1.45)$ & $(1.56)$ & $(0.61)$ & $(0.68)$ \\
\hline \multirow[t]{2}{*}{$R O A_{i, t-1}$} & $-0.031^{c}$ & $-0.029^{c}$ & $-0.032^{c}$ & $-0.031^{c}$ \\
\hline & $(-4.83)$ & $(-4.61)$ & $(-6.69)$ & $(-6.56)$ \\
\hline \multirow[t]{2}{*}{$D A_{i, t-1}$} & -0.131 & -0.133 & -0.104 & -0.104 \\
\hline & $(-1.23)$ & $(-1.25)$ & $(-1.32)$ & $(-1.33)$ \\
\hline \multirow[t]{2}{*}{ NCSKEW $_{i, t-1}$} & $0.107^{c}$ & $0.109^{c}$ & & \\
\hline & $(6.75)$ & $(6.90)$ & & \\
\hline \multirow[t]{2}{*}{ DUVOL $L_{i, t-1}$} & & & $0.117^{c}$ & $0.119^{c}$ \\
\hline & & & $(6.92)$ & $(7.04)$ \\
\hline \multirow[t]{2}{*}{ Intercept } & 0.282 & 0.333 & $0.567^{b}$ & $0.596^{\mathrm{b}}$ \\
\hline & $(0.74)$ & $(0.88)$ & $(2.01)$ & $(2.11)$ \\
\hline Fix_ind & Yes & Yes & Yes & Yes \\
\hline Fix_time & Yes & Yes & Yes & Yes \\
\hline $\operatorname{Adj}-R^{2}$ & 0.1556 & 0.1554 & 0.1801 & 0.1803 \\
\hline No. of obs. & 4832 & 4832 & 4832 & 4832 \\
\hline
\end{tabular}

Notes. This table presents the influence of ESOP price on stock price crash risk. The empirical test equation is: CrashRisk $_{i, t}=a_{0}+a_{1} \times$ Price_ESOP $_{i, t-1}\left(\right.$ R_Price_ESOP $\left._{i, t-1}\right)+a_{2} \times$ ESOP $_{i, t-1}$ $+a_{3} \times$ Control Variablest $1+\varepsilon_{i, t}$

The $t$-statistics, reported in parentheses, are based on standard errors clustered by both firm and time. Time and industry fixed effects are included. Here ${ }^{a},{ }^{b}$, and ${ }^{c}$ indicate statistical significance at the $10 \%, 5 \%$, and $1 \%$ levels, respectively

thus play an internal supervisory role? This issue is also worth testing. ESOPs link employee benefits with firm value (Hall and Murphy 2000, 2002, 2003; Huddart and Lang 1996; Jensen and Murphy 1990; Kim and Ouimet 2011). Employees of firms with ESOPs are more likely to pay attention to stock price and its influencing factors which include executive behavior. Employees are likely to be more motivated to supervise executives and express their opinions about executives' misconduct, which produces additional pressure on executives to work within ethical and legal bounds, thus reducing both the possibility of the concealment of bad news and the level of crash risk. 
It is more difficult to conceal bad news when a firm has good corporate governance and effectively supervises executive power. Crash risk will be lower and additional oversight of executives will play less of a role in reducing crash risk in this case. Conversely, executives may easily conceal bad news and a firm's crash risk is high under poor governance, without mechanisms for checks and balances of executive power. Oversight of executives is more effective in preventing information manipulation and reducing crash risk. Therefore, from the perspective of internal supervision, we predict that the influence of ESOPs on crash risk will be more pronounced for firms with poor corporate governance and unrestricted executive power.

To examine the ESOP internal supervision effect on crash risk, we design the following empirical model:

$$
\begin{aligned}
\text { CrashRisk }_{i, t}=\alpha_{0} & +\alpha_{1} \times \text { ESOP }_{i, t-1} \times \text { Monitor }_{i, t-1}+\alpha_{2} \times \text { ESOP }_{i, t-1} \\
& +\alpha_{3} \times \text { Monitor }_{i, t-1}+\alpha_{4} \times{\text { Control } \text { Variables }_{t-1}+\varepsilon_{i, t}},
\end{aligned}
$$

where Monitor $_{i, t-1}$ is the level of other types of supervision imposed on executives. We employ three proxy variables to depict a firm's existing oversight, which includes the proportion of independent directors on the board of directors (Independent), a dummy variable of whether the firm is audited by the Big Four (Big4) and executive shareholding ratio $(E x c H o l d)$.These represent the firm's internal corporate governance, external audit supervision and executive power respectively.

However, all these regression results show that there is no significant interaction between ESOPs and firms' level of oversight, which indicates that the impact of ESOPs on crash risk does not vary with changes in firms' formal supervision of executives. To control for the length of this paper and focus on our main findings, we do not report these results.

\section{Robustness tests}

\section{The effectiveness of PSM}

Since most of our empirical tests are based on PSM matched samples, if the matching itself is invalid, the conclusion of this paper would also be invalid. To test the effectiveness of our PSM method, we first run Logit regressions and $t$-tests on the full sample and matched sample (not presented).

Regression results show that firm size $\left(\right.$ Size $\left._{i, t-1}\right)$ is positively related to the adoption of an ESOP at the 1\% level, and the shareholding ratio of the largest shareholder (Fitst $t_{i, t-1}$ ) is negatively related, which means that an ESOP is influenced by these firm characteristics. The relationship between firm characteristics and the adoption of an ESOP is no longer significant after PSM. $T$-test results also show that there is no significant difference on firm size, return on assets, shareholding ratio of the largest shareholder, and leverage ratio between ESOP firms and paired ones. These empirical results indicate that our PSM approach controls the differences in characteristics between two types of firms and effectively eliminates the self-selection problem of ESOP adoption.

\section{Endogenous test using the difference-in-difference model}

The decision to adopt an ESOP is made in light of various factors, including a firm's characteristics and the previous level of crash risk. Though we use a PSM approach to control variables affecting crash risk following previous studies, endogeneity due to omitted variables may still be a problem. The relationship between ESOPs and price 
crash risk may be caused by factors not considered in this paper which affect ESOP adoption and crash risk simultaneously.

To further eliminate the endogeneity problems, we add a new variable After in the newly built panel data. The variable After is valued according to the observation date and the ESOP announcement date in ESOP firms. If the observation date is later than its ESOP announcement date, the variable After equals to 1 , and 0 otherwise. We extend the sample period to 2013 to capture firm characteristics before the ESOP announcement. The ESOP announcement date for matched firms is the same as the ESOP firms they are matched with. Then we re-examine the influence of ESOPs on stock price crash risk using the DID model as follows:

$$
\begin{gathered}
\text { CrashRisk }_{i, t}=\alpha_{0}+\alpha_{1} \times \text { ESOP }_{i, t-1} \times \text { After }+\alpha_{2} \times \text { ESOP }_{i, t-1}+\alpha_{3} \times \text { After } \\
+\alpha_{4} \times \text { Control } \text { Variables }_{t-1}+\varepsilon_{i, t} .
\end{gathered}
$$

Table 12 shows that the regression coefficients of $E S O P_{i, t-1} \times$ After $_{i, t}$ are significantly negative at the $1 \%$ level, indicating that the crash risk of firms adopting ESOP drops remarkably after the announcement of an ESOP compared with the control group. This finding is consistent with our conclusion and our main results in Table 4 are robust.

\section{ESOPs versus executive equity incentives}

Kim et al. (2011b) suggest that executive equity incentives will influence stock price crash risk. In particular, they find that CFO stock option incentives significantly increase future crash risk. As mentioned above, ESOPs are similar to executive equity incentives to some extent, and ESOPs in China do not exclude executive involvement, which may also contribute to the relationship between ESOPs and crash risk. To control for the influence of executive equity incentives on crash risk, we add executive equity incentives into the control variables and redo the regression analysis in Table 4. After these tests, our main conclusions are still robust.

\section{The justification of ESOP announcements}

We take the date in which an ESOP draft is disclosed as the ESOP announcement day; however disclosure of the ESOP draft does not mean complete adoption of an ESOP. It needs approval from the subsequent shareholders' meeting. Therefore, we collect data on shareholders' meetings and check whether the ESOP draft is voted on and adopted at the meeting to confirm the ESOP date. We then replace the ESOP announcement date with this one and re-estimate all the regressions above. After these tests, our main conclusions are still robust.

\section{Excluding free ESOPs}

Shareholding in partial ESOPs are offered by substantial shareholders for free in China. We measure the size and price of these ESOPs as 0 in previous tests, which is not entirely accurate and may in fact influence our conclusions. Therefore, we eliminate "free ESOP participation" in the robustness tests, and run all regressions above again. Our main findings remain the same. 
Table 12 ESOPs and crash risk: DID model

\begin{tabular}{|c|c|c|}
\hline Variable & NCSKEW (1) & DUVOL (2) \\
\hline \multirow[t]{2}{*}{ 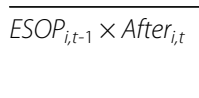 } & $-0.177^{c}$ & $-0.143^{c}$ \\
\hline & $(-3.05)$ & $(-3.00)$ \\
\hline \multirow[t]{2}{*}{$E S O P_{i, t-1}$} & -0.005 & -0.016 \\
\hline & $(-0.32)$ & $(-1.13)$ \\
\hline \multirow[t]{2}{*}{ After $_{i, t}$} & $0.093^{b}$ & $0.087^{c}$ \\
\hline & (2.39) & $(2.73)$ \\
\hline \multirow[t]{2}{*}{ Dturn $_{i, t-1}$} & $-0.019^{c}$ & $-0.01^{a}$ \\
\hline & $(-2.86)$ & $(-1.69)$ \\
\hline \multirow[t]{2}{*}{ Hret $_{i, t-1}$} & $0.318^{c}$ & $0.22^{c}$ \\
\hline & $(9.97)$ & $(7.97)$ \\
\hline \multirow[t]{2}{*}{ Sigma $_{i, t-1}$} & $-3.959^{b}$ & $-2.447^{\mathrm{a}}$ \\
\hline & $(-2.40)$ & $(-1.78)$ \\
\hline \multirow[t]{2}{*}{$M B_{i, t-1}$} & $0.013^{c}$ & $0.012^{c}$ \\
\hline & (3.78) & $(4.23)$ \\
\hline \multirow[t]{2}{*}{ Size $_{i, t-1}$} & $0.036^{c}$ & $0.052^{c}$ \\
\hline & $(3.10)$ & $(5.46)$ \\
\hline \multirow[t]{2}{*}{$\operatorname{Lev}_{i, t-1}$} & 0.046 & -0.054 \\
\hline & $(0.81)$ & $(-1.16)$ \\
\hline \multirow[t]{2}{*}{$R O A_{i, t-1}$} & 0.006 & 0.002 \\
\hline & $(1.25)$ & $(0.62)$ \\
\hline \multirow[t]{2}{*}{$D A_{i, t-1}$} & -0.116 & -0.075 \\
\hline & $(-1.35)$ & $(-1.06)$ \\
\hline \multirow[t]{2}{*}{ NCSKEW $_{i, t-1}$} & $0.079^{c}$ & \\
\hline & $(5.02)$ & \\
\hline \multirow[t]{2}{*}{ DUVOL $_{i, t-1}$} & & $0.066^{c}$ \\
\hline & & $(3.81)$ \\
\hline \multirow[t]{2}{*}{ Intercept } & $-1.362^{c}$ & $-1.689^{c}$ \\
\hline & $(-4.90)$ & $(-7.37)$ \\
\hline Fix_ind & Yes & Yes \\
\hline Fix_time & No & No \\
\hline Adj-R $R^{2}$ & 0.0487 & 0.0664 \\
\hline No. of obs. & 5517 & 5517 \\
\hline
\end{tabular}

Notes. This table reports the influence of ESOPs on crash risk using a DID model. The empirical test equation is: CrashRisk $_{i, t}=a_{0}+a_{1} \times$ ESOP $_{i, t-1} \times$ After $_{i, t}+a_{2} \times$ ESOP $_{i, t-1}+a_{3} \times$ After $_{i, t}+a_{4} \times$ Control Variables $_{t-1}+\varepsilon_{i, t}$ The $t$-statistics, reported in parentheses, are based on standard errors clustered by both firm and time. Time and industry fixed effects are included. Here ${ }^{a},{ }^{b}$, and ${ }^{c}$ indicate statistical significance at the $10 \%, 5 \%$, and $1 \%$ levels, respectively

\section{The justification of ESOP price}

The ESOP price we use in Tables 10 and 11 was obtained from ESOP drafts, an ex-ante estimation of the actual price. As an ESOP continues to exist, the actual price will deviate from previous estimations, especially when shares in the ESOP are repurchased on the secondary market. This may affect the robustness of our conclusions. Therefore, we collect information on the ESOP process and calculate the actual stock price of ESOPs using the weighted average method. We replace estimated ESOP price used in Tables 10 and 11 with the weighted average one and repeat the regressions. New regression results show that our main findings are robust. 


\section{Conclusion}

As an important initiative to comprehensively deepen reform and promote the healthy development of China's capital markets, ESOPs have received extensive attention from the government, listed firms and investors since they were first proposed. It is worthwhile to examine the influence of ESOPs on capital markets in the fields of both theory and practice. To better understand the impact of ESOPs in China, we conduct empirical tests using listed firms' announced ESOPs in Ashare markets during the time period 2014 to 2017 and their matched samples using a PSM approach.

The findings show that the adoption of ESOPs can reduce future crash risk mainly through signaling effects: ESOPs convey positive signals to capital markets that insiders are optimistic about firms' future value, which helps enhance investors' confidence, reduce the negative influence of bad information on stock price, and thus reduce stock price crash risk. Finally, we find that ESOP heterogeneity is of great importance to the influence of ESOPs on stock price crash risk. Larger scale, lower-priced, and non-leveraged ESOPs are more likely to reduce abnormal stock price fluctuations and decrease crash risk, while higher-priced and leveraged ESOPs only have a limited effect on crash risk reduction and sometimes may even raise the risk.

\section{Abbreviations}

"Opinions": Guiding Opinions on the Pilot Program for the Implementation of the Employee Share Ownership Plans by Listed Companies; CSRC: China Securities Regulatory Commission; ESOP: Employee Stock Ownership Plan; SOE: State-

Owned Enterprise

\section{Acknowledgements}

We appreciate the helpful comments and suggestions from reviewers and editors. This project is supported by Collaborative Innovation Center for State-Owned Assets Administration of Beijing Technology and Business University (CICSOAA). We thank Qingbin Meng, Xue Wang, and workshop participants at Renmin University of China, for their many excellent comments on earlier versions of our paper.

\section{Authors' contributions}

$\mathrm{YL}$ is a senior professor of Finance Department, Renmin University of China, she is also the doctoral supervisor of BS. As the first author, YL proposed the original research question, pointed out feasible research directions, and provided resources for field interviews. She also provided valuable modify advices and did much effort in the process of revision on earlier versions of the paper. BS is a doctoral candidate in Renmin University of China. He reviewed the existing literature and conducted most of the field interviews in the research, which makes the research topic to more specific detail. He also made some contributions in collecting research data manually. SY is an assistant professor of Beijing Technology and Business University. He did most of the empirical analysis and interpreted the results. He also collected part of the research data manually and did some literature review work. All authors read and approved the final manuscript.

\section{Funding}

National Natural Science Foundation of China (No. 71272150, and No. 71602005),

Key Projects of the National Social Science Research Fund of China (No. 15AZD012),

Humanities and Social Sciences Fund of the Ministry of Education (No. 15YJC630164).

\section{Availability of data and materials}

The datasets generated and analyzed during the current study are available in the CSMAR (http://cn.gtadata.com/) and WIND (http://www.wind.com.cn/) repository, which are two of the most publicly used and widely accepted database in financial and economic research. Partial characteristic data of ESOPs, such as ESOP size, price, and leverage ratio, are collected manually from provisional announcements of listed companies. They are available from the corresponding author on reasonable request.

Competing interests

The authors declare that they have no competing interests.

\section{Author details}

${ }^{1}$ Business School, Renmin University of China, Beijing 100872, China. ${ }^{2}$ Business School, Beijing Technology and Business University, Beijing 100048, China. 
Received: 27 September 2018 Accepted: 8 July 2019

Published online: 16 September 2019

\section{References}

Agrawal, A., \& Mandelker, G. N. (1987). Managerial incentives and corporate investment and financing decisions. The Journal of Finance, 42(4), 823-837.

Ahrens, C. (2018). The effect of stock based incentives on individual manager performance. In Academy of management proceedings $(2018,1,16304)$. Briarcliff Manor: Academy of Management.

Akerlof, G. A. (1982). Labor contracts as partial gift exchange. The Quarterly Journal of Economics, 97(4), 543-569.

Banerjee, A., Lampel, J., Bhalla, A. (2017). Employee ownership schemes as resilience signals during economic crisis and recovery. In Academy of management proceedings (2017, 1, 15243). Briarcliff Manor: Academy of Management.

Beatty, A. (1994). An empirical analysis of the corporate control, tax and incentive motivations for adopting leveraged employee stock ownership plans. Managerial and Decision Economics, 15(4), 299-315.

Beatty, A. (1995). The cash flow and informational effects of employee stock ownership plans. Journal of Financial Economics, $38(2), 211-240$

Brecher, A. G., Lazarus, S., III, \& Gray, W. A. (1983). The function of employee retirement plans as an impediment to takeovers. The Business Lawyer, 38(2), 503-513.

Brown, S., Fakhfakh, F., \& Sessions, J. G. (1999). Absenteeism and employee sharing: An empirical analysis based on French panel data, 1981-1991. ILR Review, 52(2), 234-251.

Buchko, A. A. (1992). Effects of employee ownership on employee attitudes: A test of three theoretical perspectives. Work and Occupations, 19(1), 59-78.

Chang, S. (1990). Employee stock ownership plans and shareholder wealth: An empirical investigation. Financial Management, 19(1), 48-58.

Chang, S., \& Mayers, D. (1992). Managerial vote ownership and shareholder wealth: Evidence from employee stock ownership plans. Journal of Financial Economics, 32(1), 103-131.

Chaplinsky, S., \& Niehaus, G. (1990). The tax and distributional effects of leveraged ESOPs. Financial Management, 19(1), 29-38.

Chaplinsky, S., \& Niehaus, G. (1994). The role of ESOPs in takeover contests. The Journal of Finance, 49(4), 1451-1470.

Chen, J., Hong, H., \& Stein, J. C. (2001). Forecasting crashes: Trading volume, past returns, and conditional skewness in stock prices. Journal of Financial Economics, 61(3), 345-381.

Chu, J., \& Fang, J. X. (2016). Margin-trading, short-selling and the deterioration of crash risk. Economic Research Journal, (5), 143-158.

Cohen, R. B., Hall, B. J., \& Viceira, L. M. (2000). Do executive stock options encourage risk-taking.

Comment, R., \& Jarrell, G. A. (1987). Two-tier and negotiated tender offers: The imprisonment of the free-riding shareholder. Journal of Financial Economics, 19(2), 283-310.

Conte, M., \& Tannenbaum, A. S. (1978). Employee-owned companies: Is the difference measurable. Monthly Labor Review, 101(7), 23-28

Conte, M. A., Blasi, J., Kruse, D., \& Jampani, R. (1996). Financial returns of public ESOP companies: Investor effects vs. manager effects. Financial Analysts Journal, 52(4), 51-61.

Core, J. E., \& Guay, W. R. (2001). Stock option plans for non-executive employees. Journal of Financial Economics, 61(2), $253-287$.

De Fusco, R. A., Johnson, R. R., \& Zorn, T. S. (1990). The effect of executive stock option plans on stockholders and bondholders. The Journal of Finance, 45(2), 617-627.

Ding, D. K., \& Sun, Q. (2001). Causes and effects of employee stock option plans: Evidence from Singapore. Pacific-Basin Finance Journal, 9(5), 563-599.

Dyck, A., Morse, A., \& Zingales, L. (2010). Who blows the whistle on corporate fraud? The Journal of Finance, 65(6), $2213-2253$.

Fang, H., Nofsinger, J. R., \& Quan, J. (2015). The effects of employee stock option plans on operating performance in Chinese firms. Journal of Banking \& Finance, 54, 141-159.

Goldstein, I., \& Guembel, A. (2008). Manipulation and the allocational role of prices. The Review of Economic Studies, 75(1), 133-164.

Gordon, L. A., \& Pound, J. (1990). ESOPs and corporate control. Journal of Financial Economics, 27(2), 525-555.

Hall, B. J., \& Murphy, K. J. (2000). Optimal exercise prices for executive stock options. American Economic Review, 90(2), 209-214.

Hall, B. J., \& Murphy, K. J. (2002). Stock options for undiversified executives. Journal of Accounting and Economics, 33(1), 3-42.

Hall, B. J., \& Murphy, K. J. (2003). The trouble with stock options. Journal of Economic Perspectives, 17(3), 49-70.

Hammer, T. H., Landau, J. C., \& Stern, R. N. (1981). Absenteeism when workers have a voice: The case of employee ownership. Journal of Applied Psychology, 66(5), 561.

Haugen, R. A., \& Senbet, L. W. (1981). Resolving the agency problems of external capital through options. The Journal of Finance, 36(3), 629-647.

Holden, S., \& van Derhei, J. (2003). 401 (k) plan asset allocation, account balances, and loan activity in 2002. EBRI Issue Brief, 28(261), 1.

Huddart, S. (1994). Employee stock options. Journal of Accounting and Economics, 18(2), 207-231.

Huddart, S., \& Lang, M. (1996). Employee stock option exercises an empirical analysis. Journal of Accounting and Economics, 21(1), 5-43.

Hutton, A. P., Marcus, A. J., \& Tehranian, H. (2009). Opaque financial reports, R2, and crash risk. Journal of Financial Economics, 94(1), 67-86.

Ismail, Z., Mahjom, N., Hashim, E., \& Dockery, E. (2016). Executive stock options plans and its effect on short-run corporate performance. Journal of Contemporary Issues and Thought, 6, 102-114.

Jensen, M. C., \& Murphy, K. J. (1990). Performance pay and top-management incentives. Journal of Political Economy, 98(2), 225-264.

Jin, L., \& Myers, S. C. (2006). R2 around the world: New theory and new tests. Journal of Financial Economics, 79(2), 257-292.

Jones, D. C., \& Pliskin, J. (1997). Determinants of the incidence of group incentives: Evidence from Canada. Canadian Journal of Economics, 30(4b), 1027-1045.

Kim, E. H., \& Ouimet, P. (2011). Employee stock ownership plans: Employee compensation and firm value. SSRN Electronic Journal. https://doi.org/10.2139/ssrn.1823745 
Kim, E. H., \& Ouimet, P. (2014). Broad-based employee stock ownership: Motives and outcomes. The Journal of Finance, 69(3), 1273-1319.

Kim, J. B., Li, Y., \& Zhang, L. (2011a). Corporate tax avoidance and stock price crash risk: Firm-level analysis. Journal of Financial Economics, 100(3), 639-662.

Kim, J. B., Li, Y., \& Zhang, L. (2011b). CFOs versus CEOs: Equity incentives and crashes. Journal of Financial Economics, 101(3), 713-730.

Kumbhakar, S. C., \& Dunbar, A. E. (1993). The elusive ESOP_Productivity link: Evidence from US firm-level data. Journal of Public Economics, 52(2), 273-283.

Mitchell, O. S., \& Utkus, S. P. (2002). The role of company stock in defined contribution plans (NBER working papers no. w9250. Cambridge: National Bureau of Economic Research.

Park, H. (2017). Company stock in defined contribution plans: Evidence from proxy voting. Financial Management, 46(1), 155-202.

Piotroski, J. D., Wong, T. J., \& Zhang, T. (2015). Political incentives to suppress negative information: Evidence from Chinese listed firms. Journal of Accounting Research, 53(2), 405-459.

Poterba, J. (2004). Valuing assets in retirement saving accounts (NBER working papers no. w10395. Cambridge: National Bureau of Economic Research.

Pugh, W. N., Oswald, S. L., \& Jahera, J. S., Jr. (2000). The effect of ESOP adoptions on corporate performance: Are there really performance changes? Managerial and Decision Economics, 21(5), 167-180.

Quarrey, M., Blasi, J. R., \& Rosen, C. M. (1986). Taking stock: Employee ownership at work. Cambridge, MA: Ballinger Publishing Company.

Rajgopal, S., \& Shevlin, T. (2002). Empirical evidence on the relation between stock option compensation and risk taking. Journal of Accounting and Economics, 33(2), 145-171.

Rauh, J. D. (2006). Own company stock in defined contribution pension plans: A takeover defense? Journal of Financial Economics, 81(2), 379-410.

Rosen, C., \& Quarrey, M. (1987). How well is employee ownership working? Harvard Business Review, 65(5), 126-132.

Shackelford, D. A. (1991). The market for tax benefits: Evidence from leveraged ESOPs. Journal of Accounting and Economics, 14(2), 117-145.

Tehranian, H., \& Waegelein, J. F. (1985). Market reaction to short-term executive compensation plan adoption. Journal of Accounting and Economics, 7(1-3), 131-144.

Triki, T., \& Ureche-Rangau, L. (2012). Stock options and firm performance: New evidence from the French market. Journal of International Financial Management \& Accounting, 23(2), 154-185.

Xu, N., Jiang, X., Chan, K. C., \& Yi, Z. (2013). Analyst coverage, optimism, and stock price crash risk: Evidence from China. Pacific-Basin Finance Journal, 25, 217-239.

\section{Publisher's Note}

Springer Nature remains neutral with regard to jurisdictional claims in published maps and institutional affiliations.

\section{Submit your manuscript to a SpringerOpen ${ }^{\circ}$ journal and benefit from:}

- Convenient online submission

- Rigorous peer review

- Open access: articles freely available online

- High visibility within the field

- Retaining the copyright to your article

Submit your next manuscript at $\boldsymbol{\nabla}$ springeropen.com 